\title{
Triphenilphosphonium Analogs of Chloramphenicol as Dual-Acting Antimicrobial and Antiproliferating Agents
}

\author{
Julia A. Pavlova ${ }^{1}$, Zimfira Z. Khairullina ${ }^{1} \mathbb{D}$, Andrey G. Tereshchenkov ${ }^{2}\left(D_{1}\right.$ Pavel A. Nazarov ${ }^{2,3}$, \\ Dmitrii A. Lukianov ${ }^{4}$, Inna A. Volynkina ${ }^{5}$, Dmitry A. Skvortsov ${ }^{1}$, Gennady I. Makarov ${ }^{6}$, Etna Abad ${ }^{7}$ (D), \\ Somay Y. Murayama ${ }^{8}$, Susumu Kajiwara ${ }^{9}$, Alena Paleskava 10,11, Andrey L. Konevega 10,11,12 (D), \\ Yuri N. Antonenko ${ }^{2} \mathbb{D}$, Alex Lyakhovich ${ }^{13,14} \mathbb{D}$, Ilya A. Osterman 1,4,15,*(D), Alexey A. Bogdanov ${ }^{1,2}$ and \\ Natalia V. Sumbatyan 1,2,*
}

\section{check for} updates

Citation: Pavlova, J.A.; Khairullina, Z.Z.; Tereshchenkov, A.G.; Nazarov, P.A.; Lukianov, D.A.; Volynkina, I.A.; Skvortsov, D.A.; Makarov, G.I.; Abad, E.; Murayama, S.Y.; et al. Triphenilphosphonium Analogs of Chloramphenicol as Dual-Acting Antimicrobial and Antiproliferating Agents. Antibiotics 2021, 10, 489. https://doi.org/10.3390/antibiotics10050489

Academic Editor: George Dinos

Received: 31 March 2021

Accepted: 19 April 2021

Published: 23 April 2021

Publisher's Note: MDPI stays neutral with regard to jurisdictional claims in published maps and institutional affiliations.

Copyright: (c) 2021 by the authors. Licensee MDPI, Basel, Switzerland. This article is an open access article distributed under the terms and conditions of the Creative Commons Attribution (CC BY) license (https:/ / creativecommons.org/licenses/by/ $4.0 /)$.
1 Department of Chemistry, Lomonosov Moscow State University, Leninskie Gory 1, 119991 Moscow, Russia; julidev@yandex.ru (J.A.P.); zkh_msu@mail.ru (Z.Z.K.); skvorratd@mail.ru (D.A.S.);

bogdanov@belozersky.msu.ru (A.A.B.)

2 A.N. Belozersky Institute of Physico-Chemical Biology, Lomonosov Moscow State University, Leninskie Gory 1, 119992 Moscow, Russia; tereshchenkov@list.ru (A.G.T.); nazarovpa@gmail.com (P.A.N.); antonen@belozersky.msu.ru (Y.N.A.)

3 Laboratory of Molecular Genetics, Moscow Institute of Physics and Technology, 141700 Dolgoprudny, Russia

4 Center of Life Sciences, Skolkovo Institute of Science and Technology, 143028 Skolkovo, Russia; Dmitrii.Lukianov@skoltech.ru

5 School of Bioengineering and Bioinformatics, Lomonosov Moscow State University, 119992 Moscow, Russia; inna-volynkina@yandex.ru

6 Laboratory of the Multiscale Modeling of Multicomponent Materials, South Ural State University, 454080 Chelyabinsk, Russia; makarovgi@susu.ru

7 Department of Experimental and Health Sciences, Universitat Pompeu Fabra, 08003 Barcelona, Spain; etna.abad@upf.edu

8 Department of Chemotherapy and Mycoses, National Institute of Infectious Diseases, 1-23-1 Toyama, Shinjuku-ku, Tokyo 162-8340, Japan; smurayam@nih.go.jp

9 School of Life Science and Technology, Tokyo Institute of Technology, Yokohama, Kanagawa 226-8501, Japan; kajiwara.s.aa@m.titech.ac.jp

10 Petersburg Nuclear Physics Institute, NRC “Kurchatov Institute”, 188300 Gatchina, Russia; polesskova_ev@pnpi.nrcki.ru (A.P.); konevega_al@pnpi.nrcki.ru (A.L.K.)

11 Peter the Great St. Petersburg Polytechnic University, 195251 Saint Petersburg, Russia

12 NRC "Kurchatov Institute", 123182 Moscow, Russia

3 Institute of Molecular Biology and Biophysics, Federal Research Center of Fundamental and Translational Medicine, 630117 Novosibirsk, Russia; lyakhovich@gmail.com

14 Vall D'Hebron Institut de Recerca, 08035 Barcelona, Spain

15 Genetics and Life Sciences Research Center, Sirius University of Science and Technology, 1 Olympic Ave, 354340 Sochi, Russia

* Correspondence: i.osterman@skoltech.ru (I.A.O.); sumbtyan@belozersky.msu.ru (N.V.S.)

Abstract: In the current work, in continuation of our recent research, we synthesized and studied new chimeric compounds, including the ribosome-targeting antibiotic chloramphenicol (CHL) and the membrane-penetrating cation triphenylphosphonium (TPP), which are linked by alkyl groups of different lengths. Using various biochemical assays, we showed that these CAM-Cn-TPP compounds bind to the bacterial ribosome, inhibit protein synthesis in vitro and in vivo in a way similar to that of the parent $\mathrm{CHL}$, and significantly reduce membrane potential. Similar to CAM-C4-TPP, the mode of action of CAM-C10-TPP and CAM-C14-TPP in bacterial ribosomes differs from that of CHL. By simulating the dynamics of CAM-Cn-TPP complexes with bacterial ribosomes, we proposed a possible explanation for the specificity of the action of these analogs in the translation process. CAM-C10-TPP and CAM-C14-TPP more strongly inhibit the growth of the Gram-positive bacteria, as compared to CHL, and suppress some CHL-resistant bacterial strains. Thus, we have shown that TPP derivatives of CHL are dual-acting compounds targeting both the ribosomes and cellular membranes of bacteria. The TPP fragment of CAM-Cn-TPP compounds has an inhibitory effect on bacteria. Moreover, since the mitochondria of eukaryotic cells possess qualities similar to those of their prokaryotic ancestors, we demonstrate the possibility of targeting chemoresistant cancer cells with these compounds. 
Keywords: chloramphenicol; alkyl(triphenyl)phosphonium; bacterial ribosome; molecular dynamics simulations; antibiotic activity; antiproliferative activity

\section{Introduction}

The search for new antimicrobial agents remains a crucial and urgent task, which is largely due to the existence and endless emergence of resistant bacterial strains with various mechanisms of acquired resistance to nearly all clinically relevant antibiotics. These mechanisms include mutations in the drug target site, enzymatic modification or degradation of antibiotics, and active efflux through porins and other permeability barriers [1-3].

One promising approach to creating new antibiotics is the development of the socalled twin-drugs-dual-acting compounds, which contain two pharmacophores covalently linked in one molecule. This approach makes it possible to potentially create drugs that are active against drug-resistant microorganisms, have an expanded spectrum of antibacterial activity, compared to the original antibiotics, and have a reduced potential for the generation of bacterial resistance [4]. While each of the two pharmacophores in such a hybrid drug molecule is expected to act independently of the original biological target, the non-cleavable covalent linker tethering the two active moieties endows the drug with a dual mechanism of action. These pharmacophores can be either two antibiotics or an antibiotic with an adjuvant that increases the access of the drug to its intracellular target (e.g., an efflux pump inhibitor or membrane and cell wall-penetrating group, or a moiety that changes the physical properties of the molecule).

Quinolone-based hybrid compounds, especially fluoroquinolones bound to other antibacterial agents, such as oxazolidinones, anilinouracil compounds, tetracyclines, benzylpyrimidine, macrolides, quinolones, oxoquinolysines, or aminoglycosides, are the most studied examples of tethered antibiotics [5-7]. Many studies on the development of dualacting compounds have been conducted on aminoglycosides by linking these molecules to quinolones, as well as to $\beta$-lactam antibiotics, $\mathrm{CHL}$, oxazolidinones, or short amphiphilic peptides. Some dual-acting glycopeptide antibiotics have been synthesized, including $\beta$-lactam, macrolide moieties, and fragments of natural antimicrobial peptides [6-8]. Many of these compounds exhibited a high antibacterial activity not only against Gram-positive strains, but also against Gram-negative bacteria, had a broad spectrum of activity and reduced the toxicity to the mammalian host, compared to the original antibiotics, and were also active against bacterial drug-resistant strains. A number of such hybrid antibiotics have had clinical success in recent years [7].

Another type of dual-acting antibiotics are hybrid compounds containing a component that inhibits efflux pumps, whose mutations are the main cause of intrinsic resistance to the currently available antibiotics against Gram-negative bacteria. This component can be either non-antibacterial $[7,9,10]$ or antibacterial $[6,7,11]$. For example, aminoquinolones or tobramycin are used to construct dual-acting agents not only as antibiotics, but also as membrane efflux pump inhibitors [11].

Another type of molecule that can be used in the design of dual-acting antibiotics are moieties that provide a better penetration of the antibiotic into bacterial cells. For example, siderophores, which are high-affinity iron chelators produced by bacteria and fungi, have been successfully used in the past to promote active transport of antibiotics into bacterial cells to enhance the action of $\beta$-lactam or penicillin antibiotics $[7,11]$.

Moreover, benzoxaboroles are known to enhance the transport of macromolecules into the cell as a result of the interaction with 1,2- and 1,3-diol polysaccharides located on the cell surface. These properties, as well as the ability of some heterocyclic boronic acids and benzoxaborole derivatives to exhibit activity against Gram-negative bacteria with multi-drug resistance, were considered when developing chimeric antibiotics based 
on glycopeptides or polyene macrocyclic antibiotics containing benzoxaboroles in their structure [6,12] and benzoxaborole derivatives of azithromycin [8].

Triphenylphosphonium (TPP) is a synthetic cation that readily penetrates biological membranes. The positive charge of this moiety is dispersed over the three phenyl residues. As a result, the water dipoles cannot be retained by the cation and, therefore, do not form an aqueous shell preventing the ion from penetrating the membrane using the energy of the transmembrane potential [13]. TPP and its synthetic derivatives have been actively studied mainly as mitochondria-targeting compounds, revealing many interesting properties that can be used to create therapeutic agents [14,15]. In particular, alkyl-TPPs and their derivatives exhibit properties of mild uncouplers of oxidative phosphorylation, with a mechanism comprising the interaction of alkyl-TPP cations with anions of fatty acids, facilitating fatty acid cycling in the membrane [16]. It has also been shown that TPP derivatives exhibit antibacterial properties [17-25]. Because of the similarity of bioenergetic processes between bacteria and mitochondria, this effect can be associated both with a decrease in the bacterial membrane potential and with destabilization of the lipid membrane due to a detergent-like effect or the induction of the non-specific membrane permeability at high concentrations of alkyl-TPP derivatives and an increase in the alkyl chain length $[17,22,23,26]$.

It has been reported that along with their antibacterial properties, TPP derivatives of various structures exhibit antiproliferative effects [27-30]. Most cancer cells possess functional mitochondria, but the oncogenic transformation itself often increases mitochondrial metabolism [31]. The mitochondria of cancer cells can have increased transmembrane potentials in comparison with normal cells [32]. However, the bioenergetics of resistant and cancer stem cells (CSCs), which are mainly responsible for metastasis, differ from the cancer cells themselves [33-35]. Ultimately, this may allow cancer cells to be discriminated according to their degree of aggressiveness. The conjugation of TPP with various bioactive compounds $[19,29,30]$ or nanocrystals [36] gives chimeric molecules an increased cellular accessibility and enhances their cytotoxicity against tumor cells. For this reason, TPP conjugates with paclitaxel [37] and doxorubicin [38] have recently been suggested to treat drug-resistant cancers. In turn, several TPP-containing compounds have been used for the elimination of cancer stem cells (CSCs) [39]. A growing body of evidence has now shown that even at low concentrations, some antibiotics can cause mitochondrial dysfunction due to similarities in their structures with bacteria $[40,41]$. On this basis, some mitochondria-targeting antibiotics have been used as anti-cancer drugs [42,43]. Overall, the synthesis of compounds combining antibiotic derivatives with targeted delivery to mitochondria via a TPP moiety may represent a novel approach in anti-cancer therapy, especially when applied to resistant forms of cancer.

CHL is a ribosome-targeting antibiotic that binds to the peptidyl transferase center (PTC) [44] of the bacterial ribosome and inhibits peptide bond formation [45]. CHL has been frequently used as a platform to obtain derivatives with an increased potency [46]. This drug is especially amenable to chemical derivatization, because its dichloroacetyl moiety can be easily replaced with a variety of other chemical scaffolds, such as amino acids [47], peptides [48], and an acyl group carrying the polyamine extension [49,50], endowing it with new properties. Thus, the synthesis of novel CHL analogs containing a TPP cation in their structure represents a promising challenge in terms of creating new potential dual-acting antibiotics and antiproliferative agents.

In the current study, we continued our research on the synthesis and exploration of semi-synthetic TPP analogs of CHL [51], i.e., CAM-Cn-TPPs, with the goal of obtaining a new group of CHL derivatives with potentially improved properties. To this end, the dichloromethyl group of the parent CHL compound was replaced with alkyl(triphenyl) phosphonium residues, resulting in CAM-Cn-TPP molecules (Figure 1). Using a competition binding assay, CAM-C10-TPP was shown to exhibit a stronger binding to the bacterial ribosome, compared to $\mathrm{CHL}$, and the new $\mathrm{CHL}$ analogs also inhibited protein synthesis in vitro. A toeprinting assay revealed that the mode of action of CAM-Cn-TPP on the bacterial ribosome differs from the site-specific action of $\mathrm{CHL}$, as previously shown for 
CAM-C4-TPP [51]. While the atomic-resolution structure of the ribosome-bound CAM-C4TPP compound has been solved and reported recently, possible interactions of the other CAM-Cn-TPP compounds with the E. coli ribosome were modeled by molecular dynamics simulations. Using a potential-sensitive fluorescent probe, we found that CAM-C10-TPP and CAM-C14-TPP significantly reduce the membrane potential in Bacillus subtilis cells. Experiments with bacteria demonstrated that, in comparison to CHL, CAM-C10-TPP inhibited the growth of the Gram-positive bacteria, Staphylococcus aureus, Listeria monocytogenes, Bacillus subtilis, and Mycobacterium smegmatis, to a greater extent. In addition, CAM-C10-TPP and CAM-C14-TPP suppressed some strains of CHL-resistant bacteria. Thus, we showed that CAM-Cn-TPP compounds act both on the ribosome and on bacterial cell membranes, with the TPP fragments of CAM-C10-TPP and CAM-C14-TPP contributing significantly to the inhibitory effect on bacterial growth. We also showed that TPP derivatives are able to target mitochondria in chemoresistant breast cancer cells and derived cancer stem-like cells and reduce their proliferation.

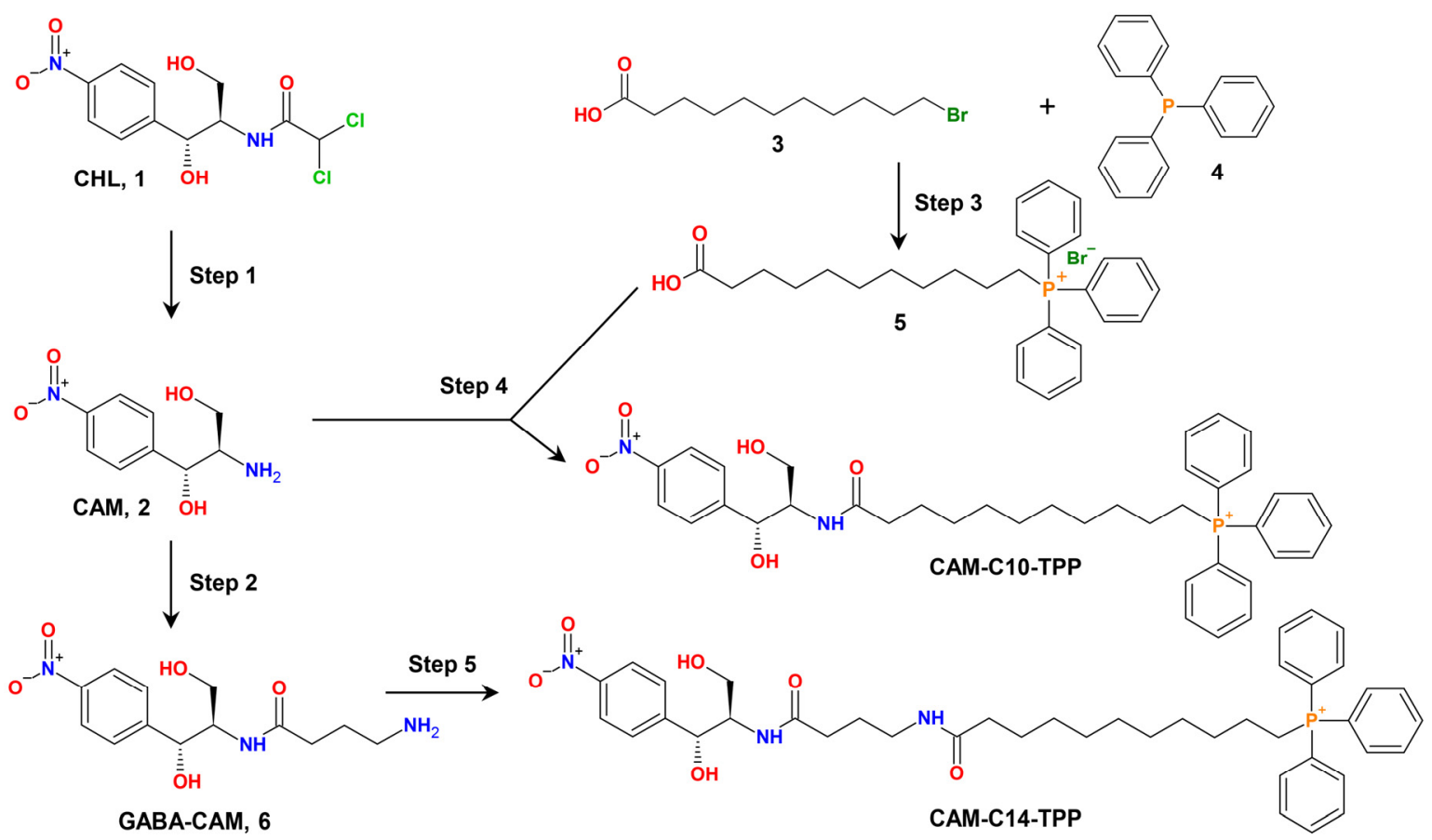

Figure 1. Scheme of the chemical synthesis of triphenylphosphonium (TPP) analogs of CHL: CAM-C10-TPP and CAM-C14TPP. Step 1: $1 \mathrm{M}$ hydrochloric acid $(\mathrm{HCl})$ at $100^{\circ} \mathrm{C}$ for $2 \mathrm{~h}$. Step 2: (1) Boc-GABA-OSu, dimethylformamide (DMF), and diisopropylethylamine (DIPEA) at $25^{\circ} \mathrm{C}$ for $24 \mathrm{~h}$; and (2) trifluoroacetic acid (TFA) at $25{ }^{\circ} \mathrm{C}$ for $30 \mathrm{~min}$. Step 3: benzene at $85^{\circ} \mathrm{C}$ for $12 \mathrm{~h}$. Step 4: (1) 5, 1-hydroxysuccinimide (HOSu), $N, N^{\prime}$-dicyclohexylcarbodiimide (DCC), and dichloromethane $\left(\mathrm{CH}_{2} \mathrm{Cl}_{2}\right)$ at $0{ }^{\circ} \mathrm{C}$ for $2 \mathrm{~h}$, then overnight at RT; (2) 2, DIPEA, DMF, and stirring at RT for $5 \mathrm{~h}$, then overnight at $4{ }^{\circ} \mathrm{C}$. Step 5: (1) 5, HOSu, DCC, and dichloromethane $\left(\mathrm{CH}_{2} \mathrm{Cl}_{2}\right)$ at $0{ }^{\circ} \mathrm{C}$ for $2 \mathrm{~h}$, then overnight at RT; (2) 6, DIPEA, DMF, and stirring at RT for $5 \mathrm{~h}$.

\section{Results and Discussion}

\subsection{Synthesis of CAM-Cn-TPPs}

We have recently synthesized and extensively characterized the first semi-synthetic TPP analogs of CHL, CAM-C4-TPP [51]. In the current study, we continued our research on the TPP analogs of CHL, synthesized two more of them, CAM-C10-TPP and CAMC14-TPP, and explored their inhibitory properties for the potential development of novel antimicrobials, as well as antiproliferative agents.

The dual-action mechanism of these compounds should be mediated, on the one hand, by their binding and action on the bacterial ribosome (similar to the action of CHL), and, on the other hand, by their action on bacterial membranes (similar to alkyl-TPP salts). For 
this purpose, the dichloromethyl group of CHL was replaced with an alkyl-TPP moiety, resulting in CAM-Cn-TPP molecules (Figure 1).

These compounds were designed with the idea that the amphenicol moiety would anchor the compound in the canonical CHL binding site within the PTC of the bacterial ribosome, and an additional group would form multiple interactions with the walls of the nascent peptide exit tunnel (NPET). We chose TPP as such a group because its positive charge, delocalized over the relatively large hydrophobic surface of the benzene rings, can provide non-specific interactions with negatively charged phosphates of the 23S rRNA, and its three phenyl rings may be available for stacking with nucleobases. In the case of CAM-C4-TPP [51], we showed how this analog binds to the bacterial ribosome and inhibits bacterial protein synthesis, both in vitro and in vivo. Moreover, according to our rational design hypothesis, the TPP group in these compounds should allow CAM-Cn-TPPs into bacterial cells, since the TPP itself is known to be a membrane-penetrating cation [13].

As for the interactions with the ribosome, we expected that linkers of variable lengths connecting the two terminal parts of these compounds (CAM and TPP) would ensure the optimal binding of CAM-Cn-TPPs to the ribosome and enable similar non-specific interactions with rRNA nucleotides at different depths of the NPET, as observed in the X-ray crystal structure of the Thermus thermophilus $70 S$ ribosome in the complex with the CAM-C4-TPP [51]. The choice of linker length was also based on the data on the inhibition of bacterial growth by alkyl-TPPs, where it was shown that the toxic effect on different bacterial species increases with increasing lipophilicity, and this effect is related to the different permeability of bacterial coats for alkyl-TPPs [17]. In addition, we modeled the length of the linkers using in silico simulations. Linkers of lengths 10 (C10) and 14 (C14) from the methylene groups were chosen. In the latter case, an amide group was introduced to reduce any possible side effects associated with the high lipophilicity of the resulting compound.

The synthesis of CAM-C10-TPP and CAM-C14-TPP was performed by the acylation of chloramphenicol amine (CAM) with carboxyl derivatives of TPP using succinimide ester (Figure 1), which is similar to the synthesis of CAM-C4-TPP [51]. The chemical structures of the obtained CAM-Cn-TPP molecules were confirmed by mass-spectrometric analysis, as well as by $1 \mathrm{H}-, 13 \mathrm{C}-$, and 31P-NMR.

\subsection{CAM-Cn-TPPs Bind to the Bacterial Ribosome with Different Affinities and Inhibit Protein Synthesis, Allowing the Formation of Short Peptides}

All new semi-synthetic CAM-Cn-TPP compounds were expected to bind and act on bacterial ribosomes by inhibiting protein synthesis, which is similar to CAM-C4-TPP and the PTC-targeting parent antibiotic CHL. To assess the affinity of CAM-C10-TPP and CAMC14-TPP for the bacterial 70S ribosome (Figure 2A), a competition-binding assay exploiting BODIPY-labeled erythromycin (BODIPY-ERY) was used [47,52,53]. CAM-C10-TPP was found to have significantly greater ( $\sim 7$-fold) affinity to the ribosome, compared to the parent $\mathrm{CHL}$, and a slightly greater affinity $(\sim 1.5$-fold $)$, compared to CAM-C4-TPP $\left(\mathrm{K}_{\text {Dapp }}=\right.$ $0.4 \pm 0.04 \mu \mathrm{M}$ for CAM-C10-TPP vs. $2.8 \pm 0.4 \mu \mathrm{M}$ for CHL; and $\mathrm{K}_{\text {Dapp }}=0.61 \pm 0.07 \mu \mathrm{M}$ for CAM-C4-TPP [51]). Unexpectedly, CAM-C14-TPP binds to the 70S ribosome with a significantly lower affinity, compared to other CAM-Cn-TPPs ( 60-90-fold) and CHL ( 13fold, $\mathrm{K}_{\mathrm{Dapp}}=36 \pm 9 \mu \mathrm{M}$ for CAM-C14-TPP). It is likely that in the case of CAM-C14-TPP, the linker may be too long, preventing the optimal positioning of the TPP moiety in the NPET. Thus, CAM-C10-TPP and CAM-C14-TPP bind to the bacterial ribosome. However, their affinity strongly depends on the length of the linker connecting the two chromophores. Among the three CAM-Cn-TPPs, the C10-linker was optimal in terms of its ability to bind to the 705 ribosome. 

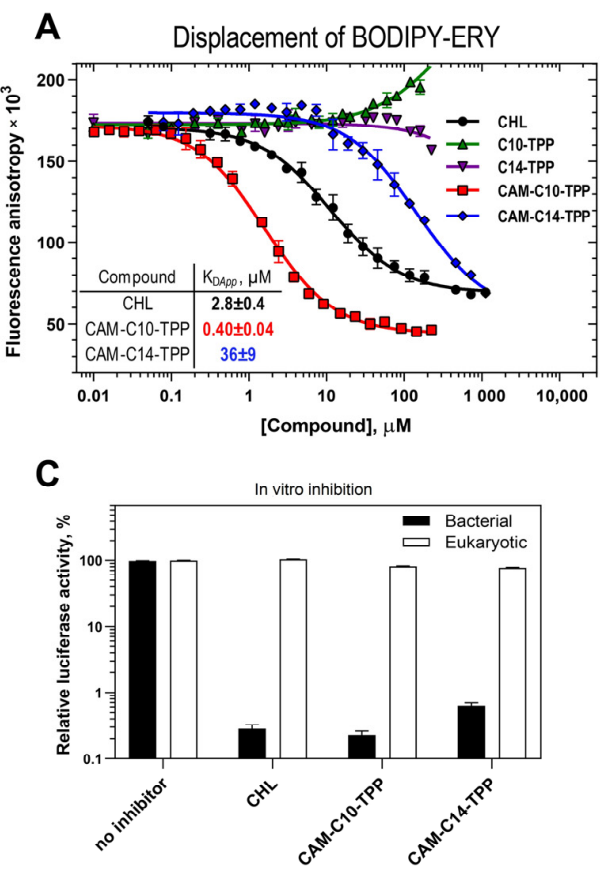

B

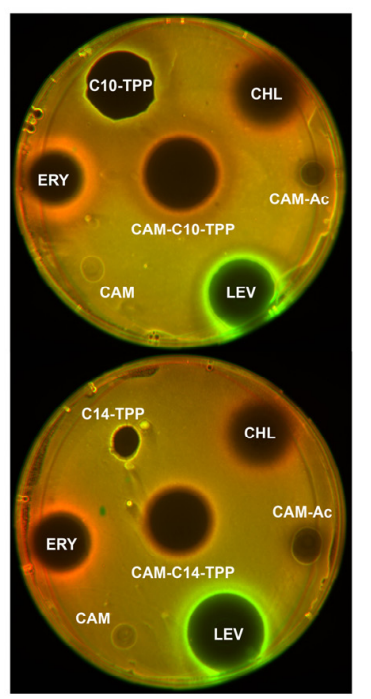

D

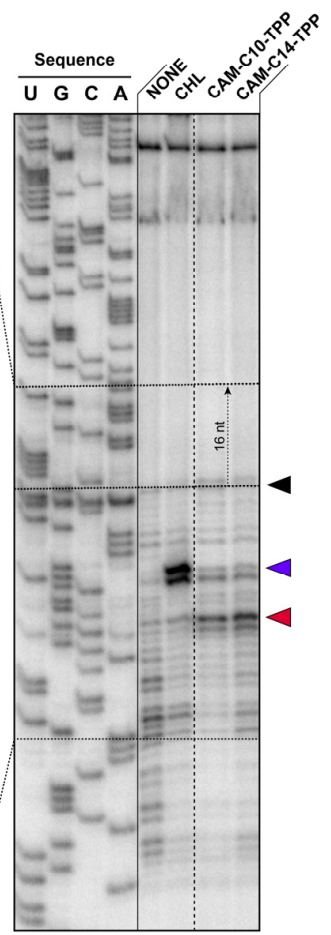

Figure 2. Binding affinity to bacterial ribosomes and the inhibition of protein synthesis by CAM-C10-TPP and CAMC14-TPP. (A) A competition-binding assay to test the displacement of fluorescently labeled analogs of the erythromycin, BODIPY-ERY, from E. coli $70 S$ ribosomes in the presence of increasing concentrations of CHL (black circles), CAM-C10TPP (red squares), CAM-C14-TPP (blue rhombus), decyl(triphenyl)phosphonium bromide (C10-TPP, green triangles), or tetradecyl(triphenyl)phosphonium bromide (C14-TPP, purple triangles), measured by fluorescence anisotropy. All reactions were repeated four times. Error bars represent the standard deviation. The resulting values for the apparent dissociation constants ( $\mathrm{K}_{\text {Dapp }}$ ) are shown on the plot. (B) Testing of the CAM-C10-TPP and CAM-C14-TPP activity using E. coli BW25113 $\triangle t o l C p D u a l r e p 2$ reporter strain. The induction of the red fluorescent protein expression (green halo around the inhibition zone, pseudocolor) is triggered by DNA-damage, while the induction of Katushka2S protein (red halo) occurs in response to ribosome stalling. Levofloxacin (LEV), erythromycin (ERY), chloramphenicol (CHL), N-acetyl-chloramphenicol amine (CAM-Ac), C10-TPP, and C14-TPP are used as the controls. (C) The inhibition of protein synthesis by $30 \mu \mathrm{M}$ of CHL, CAM-C10-TPP, or CAM-C14-TPP in vitro in the cell-free bacterial (black columns) and eukaryotic (transparent columns) transcription-translation coupled system. The relative enzymatic activity of in vitro synthesized firefly luciferase is shown. The error-bars represent the standard deviations of the mean of three independent measurements. (D) Ribosome stalling by CAM-Cn-TPP on trpL mRNA in comparison with CHL, as detected by a reverse-transcription primer-extension inhibition (toeprinting) assay in a cell-free translation system. The nucleotide sequences of $\operatorname{tr} L \mathrm{mRNA}$ and their corresponding amino acid sequences are shown on the left. The black arrowhead marks the translation arrest at the start codon, while the colored arrowheads point to drug-induced arrest sites within the coding sequences of the mRNAs used. Note that due to the large size of the ribosome, the reverse transcriptase used in the toeprinting assay stops 16 nucleotides downstream of the codon located in the P-site.

Next, we tested the effects of CAM-C10-TPP and CAM-C14-TPP in bacterial cells using an E. coli $\triangle t$ tolC-based reporter system, which is designed to screen inhibitors targeting either protein synthesis or DNA replication [54]. In this reporter system, the gene of the far-red fluorescent protein, katushka $2 S$, is inserted downstream of the genetically modified tryptophan attenuator, making it possible to express Katushka2S only upon exposure to ribosome-stalling compounds (Figure 2B, CHL and ERY, red pseudocolor rings). The red fluorescent protein gene $r f p$ is placed under the control of the SOS-inducible sulA promoter, allowingthe expression of the Red Fluorescent Protein (RFP) reporter to be determined under the action of appropriate compounds such as DNA gyrase inhibitors (e.g., levofloxacin, LEV, Figure 2B, green pseudocolored rings). 
We used chloramphenicol amine (CAM), N-acetyl-chloramphenicol amine (CAM-Ac), and alkyl-TPP (C10-TPP and C14-TPP) as negative controls in this assay. We observed neither the induction of either of the two reporters (no colored rings) nor the inhibition of cell growth by CAM or CAM-Ac (no dark zone in the middle). This indicates that the removal of the two $\mathrm{Cl}$ atoms from the dichloroacetyl group of CHL makes it inactive [55]. The C10-TPP and C14-TPP compounds (lacking the CAM moiety) inhibit bacterial cell growth (dark area in the middle) but do not induce either of the two reporters, suggesting that they act through an entirely different cellular target (likely targeting the membrane [17]). For CAM-C10-TPP and CAM-C14-TPP, as well as for the positive controls, CHL and ERY, red pseudocolor rings are observed due to the expression of the fluorescent protein, Katushka2S (but not RFP), indicating that these compounds specifically inhibit protein synthesis, as was previously observed for CAM-C4-TPP [51].

The next step was to test the new CAM-Cn-TPP compounds for their ability to inhibit the synthesis of the firefly luciferase reporter in vitro in a cell-free transcription-translation system based on an E. coli S30 extract. CAM-C10-TPP, like CAM-C14-TPP, inhibits bacterial translation, which is similar to CHL (Figure 2C) and CAM-C4-TPP [51]. At the same time, both CAM-C10-TPP and CAM-C14-TPP had no effect on eukaryotic in vitro translation (Figure 2C), which was revealed by a similar approach using the eukaryotic in vitro translation system.

Recently, it was shown that the mechanism of action of CHL on translation is different from what was previously widely accepted (blocking the accommodation of the incoming aminoacyl-tRNA in the PTC): in the presence of CHL, short peptides can be synthesized on the ribosome, and the action of the antibiotic is context-specific [56]. CHL arrests translation only when alanine and, to a lesser extent, serine or threonine appear in the penultimate position (E site) of the growing polypeptide chain and only if there is no glycyl-tRNA in the A site of the ribosome [56]. As shown in our recent study, the action of CAM-C4-TPP in bacterial translation was also context-specific, but its mode of action was different from the site-specific action of CHL [51].

To investigate the mechanism of action of CAM-C10-TPP and CAM-C14-TPP in the translation process, a primer extension inhibition assay (toeprinting) was used. This method allows for the unambiguous identification of drug-induced ribosome stalling sites along the mRNA, with single-nucleotide precision [57]. This technique is also used to determine the context-specificity of antibiotic action [56]. For this experiment, trpL mRNAs were chosen as the template, as in the pDualrep2 reporter system. In contrast to CHL, which stalls ribosomes at the Ile4 codon (Figure 2D and Figure S1, blue arrowhead) of the corresponding Ala3 in the penultimate position of the growing polypeptide chains (E-site), CAM-C10-TPP, CAM-C14-TPP, and CAM-C4-TPP blocked the ribosome progression at Val6 (Figure 2D, red arrowhead) and slightly blocked it at Ile4. Compared to the results obtained previously for CAM-C4-TPP using rst1 and rst2 mRNA templates [51], more unambiguous results were obtained using a $\operatorname{tr} p L$ mRNA template. The main drug-induced ribosome stalling sites are different for CHL and CAM-Cn-TPP, and there are also CAM-CnTPP-specific stalling positions. These results support the conclusion that CAM-Cn-TPPs have an idiosyncratic mode of action and a unique context-specificity that differs from that of the original CHL [51].

\subsection{Possible CAM-Cn-TPPs Interaction Dynamics during Translation}

To assess the possible interactions of CAM-Cn-TPPs with the ribosome during translation, we modeled the structures of complexes of the new compounds, CAM-C10-TPP and CAM-C14-TPP, with the E. coli $70 S$ ribosome using molecular dynamics simulations. To this end, we used the structure of the E. coli $70 S$ ribosome in the classical non-rotated a/A-p/P-state, which is conformationally similar to the ribosome containing tRNAs during translation [58]. Analysis of the most populated clusters (Figure 3, Table S1) for CAM-CnTPP complexes revealed that all these compounds are able to interact quite stably with the non-canonical CHL binding site [59]. The CAM-C10-TPP complex is characterized by the 
most stable stacking interactions and hydrogen bonding and is similar to the analogous CHL complex. Obviously, the positive charge of the TPP fragment is responsible for the nonspecific affinity of all CAM-Cn-TPPs to the negatively charged rRNA.
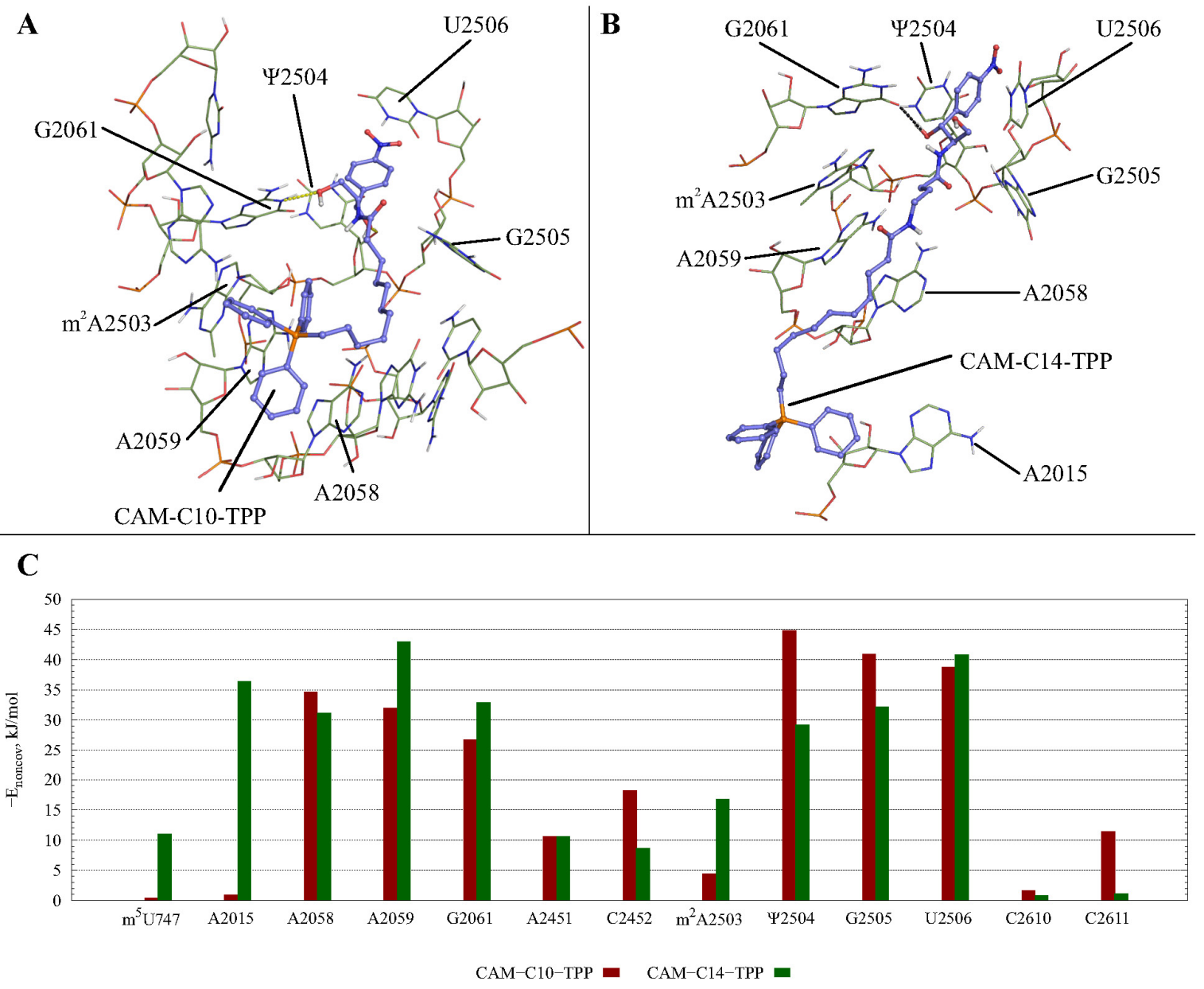

Figure 3. Interactions between CAM-C10-TPP (A), CAM-C14-TPP (B), and E. coli A,A/P,P-ribosome, obtained using MD simulations. Hydrogen bonds are shown by black dashes. CAM-Cn-TPP nitrophenyl fragment is immersed in the "hydrophobic cavity" formed by the $\Psi 2504$ and U2506 bases, forming stacking interactions with them. The arrangement of hydrogen bonds for the CAM-C10-TPP complex (A) corresponds to the non-canonically linked CHL [59]. For CAM-C14-TPP (B), a stable hydrogen bond between the O1-hydroxyl group of the CAM residue and O6 of G2061 is observed. The TPP fragment of CAM-C10-TPP interacts with the "hydrophobic cavity" of the macrolide binding site, forming developed hydrophobic contacts with the A2058, A2059, and C2610 bases. The long C14-linker in CAM-C14-TPP appears in the "hydrophobic cavity" between the A2058 and A2059 bases, and the TPP fragment is located deeper in the NPET adjacent to the residue, A2015. (C) The energy of the noncovalent interactions between CAM-C10-TPP (red columns) or CAM-C14-TPP (green columns) and the neighboring $23 \mathrm{~S}$ rRNA residues of the E. coli ribosome, which are in the canonical A,A/P,P-state. $E_{\text {noncov }}$ is shown with a negative sign for improved readability.

CAM-Cn-TPPs were constructed as bidentate ligands, differing in the length of the flexible alkyl chain linking CAM- and TPP- moieties. The synergism of the interactions of these two basic structural elements with one or the other region of the NPET depends on the length of the CAM-Cn-TPP linker. Thus, the relatively long and flexible alkyl chain of CAM-C10-TPP allows the CAM and TPP residues to adapt to their binding sites in the NPET (Figure 3A,B). On the contrary, the longer linker in the CAM-C14-TPP structure results in the inability of this compound to fit snugly in the space between the optimally bound CAM and TPP fragments. These findings may explain the higher affinity of the CAM-C10-TPP to the bacterial ribosomes, compared to the CAM-C14-TPP. 
It is noteworthy that models of CAM-Cn-TPPs complexes with the E. coli ribosome in the canonical $\mathrm{A}, \mathrm{A} / \mathrm{P}, \mathrm{P}$-state described above are in agreement with the foregoing data on translation arrest in the presence of CAM-C10-TPP and CAM-C14-TPP (Figure 2D) or CAM-C4-TPP, as described in [51]. For all three mRNA templates, trpL for CAM-C10-TPP and CAM-C14-TPP, and trpL, rst1, and rst2 for CAM-C4-TPP, the peptides synthesized before arrest contain sequences corresponding to the -2 to -5 codon regions ( 2 to 5 amino acid residues from the C-terminus of the nascent peptide), consisting of amino acids mainly with hydrophobic and aromatic side groups, which may be near CAM-Cn-TPP during translation in NPET. These positions are occupied by the A-4IF-2 in the case of $\operatorname{trp} L$, $\mathrm{W}-5 \mathrm{VT}-3$ in the case of $r s t 1$, and F-5AI-3 in the case of rst 2 templates. Obviously, these amino acids are capable of forming hydrophobic contacts with the TPP residue of CAM-Cn-TPP, so that the nascent peptide can bind firmly in the NPET, thus hindering translation.

\subsection{CAM-Cn-TPP Cause a Decrease in the Membrane Potential of B. subtilis}

As noted in the Introduction, alkyl-TPPs and their derivatives exhibit an antibacterial effect, which is associated with a decrease in the membrane potential of bacteria $[17,22,23]$. Thus, we further examined the effect of CAM-Cn-TPP on the bacterial membrane potential of B. subtilis. In particular, the membrane potential of B. subtilis can be estimated from the fluorescence of the potential-sensitive dye, DiS-C3-(5), by measuring the changing fluorescence. The potential-dependent accumulation of the dye inside the bacterial cell causes quenching and leads to a decrease in fluorescence. Under the influence of substances that reduce the membrane potential, the dye is released and the fluorescence increases. As shown in Figure 4, submicromolar concentrations of CAM-C10-TPP and CAM-C14-TPP caused a decrease in the membrane potential of $B$. subtilis on a minute time scale, whereas $10 \mu \mathrm{M}$ of CAM-C10-TPP or CAM-C14-TPP caused a rapid drop in the membrane potential to the level observed with the channel-forming antibiotic gramicidin A, which is known to cause the membrane potential of bacteria to vanish, whereas CAM-C4-TPP only takes effect at high (10 $\mu \mathrm{M}$ or more) concentrations. Therefore, the action of CAM-Cn-TPP may have a double effect on bacterial cells and be based on the depolarization of the bacterial membrane by analogy with the mechanism of action of Cn-TPP [17].

\subsection{CAM-C10-TPP and CAM-C14-TPP Inhibit Bacterial Growth}

In order to check whether the synthesized compounds are antimicrobial agents, we tested their action on a number of bacterial species (Tables 1, 2 and S2). Both CHL and alkyl-TPPs are known to act on Gram-positive bacteria [17,49]. CAM-C10-TPP and CAMC14-TPP were found to be able to inhibit the growth of the S. aureus, L. monocytogenes, $B$. subtilis, and Mycobacterium sp. strains. Moreover, CAM-C10-TPP suppressed the bacterial growth more effectively than CHL, depending on the strain (Table 1). CAM-C10-TPP was also found to inhibit CHL-resistant E. coli strains (Table S2).

Table 1. Suppression of the growth of Gram-positive bacteria by CAM-Cn-TPPs. Values of the minimal inhibitory concentration (MIC, $\mu \mathrm{M}$ ) are shown ${ }^{1}$.

\begin{tabular}{ccccc}
\hline & $\begin{array}{c}\text { Staphylococcus } \\
\text { aureus }\end{array}$ & $\begin{array}{c}\text { Listeria } \\
\text { monocytogenes }\end{array}$ & $\begin{array}{c}\text { Bacillus } \\
\text { subtilis }\end{array}$ & $\begin{array}{c}\text { Mycobacterium } \\
\text { smegmatis }\end{array}$ \\
\hline CHL & 60 & 25 & 12 & 6 \\
CAM-C10-TPP & 5 & 6 & 2 & 2 \\
CAM-C14-TPP & 12 & 17 & 12 & 8 \\
C10-TPP & 2 & 5 & 2 & $<2$ \\
C14-TPP & 1.6 & 2 & 8 & 4 \\
\hline
\end{tabular}

${ }^{1}$ MIC values were determined using the double-dilution method. The MIC for each compound was determined in triplicate in two independent sets. 
Table 2. Suppression of the growth of E. coli strains, with the deletion of the tolC gene and the harboring CHL acetyltransferase (cat) gene (E.coli $\Delta$ tolC-CAT) or B. subtilis CHL-resistant strains (B. subtilis $p H T 01$-cat) and the harboring methyltransferase Cfr (cfr) gene (B. subtilis $p H T 01-c f r$ ) by CAM-Cn-TPPs. The values of a minimal inhibitory concentration (MIC, $\mu \mathrm{M})$ are shown ${ }^{1}$.

\begin{tabular}{|c|c|c|c|c|c|}
\hline & $\begin{array}{l}\text { E. coli } \\
\Delta \text { tolC }\end{array}$ & $\begin{array}{c}\text { E. coli } \\
\Delta \text { tolC-CAT }\end{array}$ & $\begin{array}{c}\text { Bacillus } \\
\text { subtilis }\end{array}$ & $\begin{array}{l}\text { B. subtilis } \\
\text { pHT01-cat }\end{array}$ & $\begin{array}{l}\text { B. subtilis } \\
\text { pHT01-cfr }\end{array}$ \\
\hline CHL & 2.8 & $>360$ & 12 & 180 & 90 \\
\hline CAM-C10-TPP & 3 & 25 & 2 & 6 & 6 \\
\hline CAM-C14-TPP & 12.5 & 12.5 & 12 & 12.5 & 6 \\
\hline C10-TPP & 3 & 3 & 2 & 1.6 & 0.8 \\
\hline C14-TPP & 1.6 & 6 & 8 & 1.6 & 0.8 \\
\hline
\end{tabular}

1 The MIC values were determined using the double-dilution method. The MIC for each compound was determined in triplicate in two independent sets.

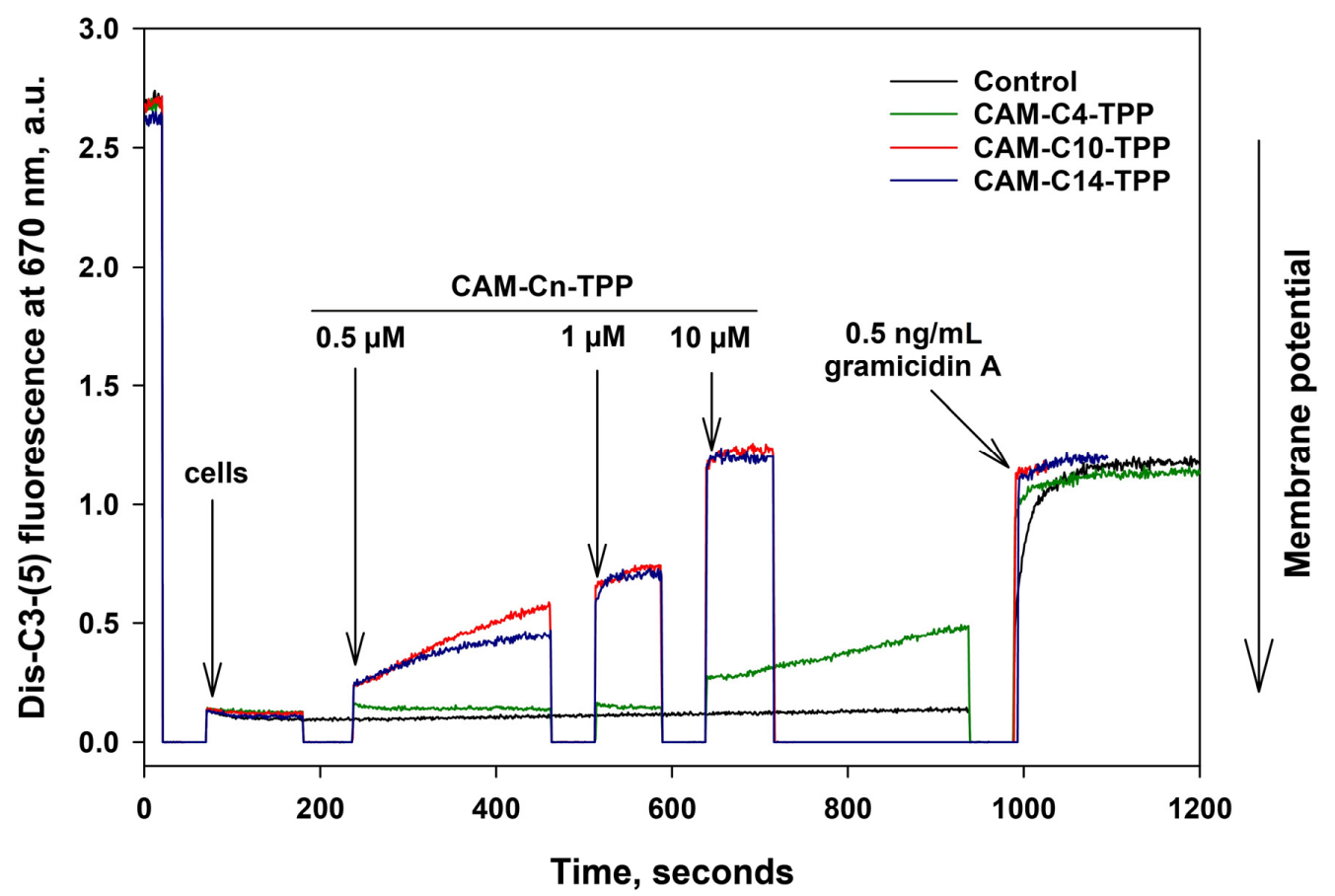

Figure 4. Dose-dependent effect of CAM-Cn-TPP on the kinetics of the membrane potential of $B$. subtilis cells, as assessed by DiS-C3-(5) $(10 \mu \mathrm{M})$ fluorescence in a PBS buffer. To reach the desired concentrations, appropriate amounts of CAM-Cn-TPP were added at different moments, which are marked by the arrows. The Gramicidin A concentration was $0.5 \mathrm{ng} / \mathrm{mL}$.

These findings prompted us to further investigate the antibacterial activity of CAMCn-TPP on CHL-resistant strains of B. subtilis and E. coli, with the tolC genes deleted, which are more sensitive to the action of compounds that might otherwise be pumped out of the Gram-negative bacterial cells by the TolC efflux pump. AcrAB-TolC is the main multi-drug resistance transporter of Gram-negative bacteria, which is responsible for the efflux of C10-TPP derivatives $[18,60]$. Apparently, the efflux of CAM-Cn-TPP is also mediated by this transporter, but the degree of involvement of other TolC-containing transporters in CAM-Cn-TPP efflux has not yet been clearly defined.

E. coli $\triangle$ tolC CHL-resistant strain harboring plasmid encoding for chloramphenicol acetyltransferase (cat) ( $p C A 24 N-L a c Z$ ) and the control E. coli $\Delta$ tolC strain was used to evaluate the inhibitory effect of the compounds. CHL-resistant strains of B. subtilis pHT01cat and B. subtilis pHT01-cfr were prepared by means of a transformation of a B. subtilis 168 strain with plasmids harboring the cat and cfr genes (chloramphenicol-florfenicol resistance) gene. The $c f r$ gene encodes for the methyltransferase, which catalyzes the methylation of $\mathrm{m}^{2} \mathrm{~A} 2503$ in the $23 \mathrm{~S}$ rRNA and causes resistance to a variety of ribosome-targeting antibiotics that bind in the A site of the bacterial ribosome [61]. 
As follows from the data in Table 2, CAM-C10-TPP inhibited the growth of E. coli $\triangle t o l C$ strain with the same efficiency as CHL, and CAM-C14-TPP inhibited it with a slightly lower efficiency. In contrast, CAM-Cn-TPPs were significantly more effective against CHL-resistant strains in comparison with CHL. At the same time, the MIC values for $\mathrm{Cn}$-TPP on all tested strains were lower than those for CAM-Cn-TPPs. A similar effect was observed for CHL-resistant $B$. subtilis because of the presence of the cat or $c f r$ genes. While CAM-Cn-TPPs clearly inhibit protein biosynthesis in bacteria in vitro, damage to bacterial membranes due to the presence of an alkyl-TPP fragment in their structure contributes more to the action of CAM-Cn-TPPs at the cellular level.

If we compare the TPP analogs of CHL with the nearest structural analogs exhibiting antimicrobial activity, in which two pharmacophores are conjugated through the alkyl linker, we can note that the antibacterial effect of these compounds is due to the fact that they either bind to bacterial ribosomes or inhibit translation in bacteria, like polyamide analogs of CHL [49,50], or disrupt the membrane potential of bacteria, since the alkyl TPP conjugates with fluorescein $[22,23]$ or coumarin $[20,21]$, while CAM-Cn-TPPs can exhibit both these effects.

\subsection{CAM-C10-TPP and CAM-C14-TPP Show a Reduced Toxicity Compared to Alkyl-TPP on Mammalian Cells}

As we have already shown, CAM-Cn-TPPs have no noticeable effect on the eukaryotic translation process (Figure 2C). Given the obvious antibacterial activity of CAM-C10-TPP and CAM-C14-TPP, it was important to assess their cytotoxicity for mammalian cells. The Mosman ("MTT") assay was used for this purpose [62].

CAM-C10-TPP and CAM-C14-TPP are more toxic to various eukaryotic cell lines in comparison to CHL (Table 3), but at the same time, they are significantly less toxic than the well-known cytotoxic drug doxorubicin, which we used as a highly toxic control. Notably, CAM-Cn-TPPs were less toxic than the corresponding alkyl-TPPs, which are part of the molecular structures of these analogs, and were also used (as bromides) as control compounds. Alkyl-TPPs are known to be quite toxic, and the toxicity effect seems to be mainly due to their ability to accumulate in mitochondria [63,64]. On the other hand, this effect may be caused by a decrease of cellular metabolism under the influence of TPP derivatives, which may be a consequence of a charge change on the cell membrane, i.e., the same effect that provides them with antibacterial properties [24-26].

Table 3. Growth inhibition by CAM-Cn-TPPs in relation to a number of cell lines according to the MTT assay. Values of a 50\% growth inhibition concentration $(\mathrm{GI} 50, \mu \mathrm{M})$ are shown.

\begin{tabular}{ccccc}
\hline & HEK293T & MCF7 & A549 & VA13 \\
\hline CHL & $>50$ & $>50$ & $>50$ & $>50$ \\
CAM-C10-TPP & $0.62 \pm 0.04$ & $1.0 \pm 0.1$ & $0.7 \pm 0.1$ & $2.8 \pm 0.5$ \\
CAM-C14-TPP & $3.6 \pm 0.5$ & $5.8 \pm 0.8$ & $2.9 \pm 0.4$ & $5.2 \pm 0.9$ \\
C10-TPP & $0.08 \pm 0.01$ & $0.21 \pm 0.03$ & $0.07 \pm 0.01$ & $0.27 \pm 0.05$ \\
C14-TPP & $0.03 \pm 0.02$ & $0.02 \pm 0.01$ & $0.025 \pm 0.009$ & $0.07 \pm 0.05$ \\
Doxorubicin & $0.007 \pm 0.001$ & $0.04 \pm 0.01$ & $0.04 \pm 0.01$ & $0.18 \pm 0.04$ \\
\hline
\end{tabular}

The relatively high toxicity of CAM-Cn-TPP to human adenocarcinoma cells (MCF7 and A549, Table 3) may indicate that these compounds can be used as antiproliferative agents. CAM-C10-TPP and CAM-C14-TPP have approximately 4-2 times the selectivity of action for A549 and noncancerous VA13 cell lines. These results are consistent with previous reports $[65,66]$ that showed that delocalized lipophilic cation-containing compounds may have selective cytotoxicity against cancer cells. Otherwise, their selectivity against cancer cell lines was lacking, compared to the HEK293T cells of a noncancerous etiology, but they are compatible with the growth rate of cancer cells. 


\subsection{Anticancer Activities of CAM-C10-TPP and CAM-C14-TPP}

We recently provided in vivo [67] and in vitro [68] evidence that certain bactericidal antibiotics suppress tumor growth by inducing mitochondrial dysfunction. Our results showed that antibiotics preferentially suppress the growth of cancer chemoresistant and the so-called cancer stem cells (CSC), two major categories of cells responsible for cancer recurrence and metastasis [41]. These cells differ from the corresponding parental cells and display a different response to the same microenvironmental stimuli, allowing them to reduce their proliferating rate and survive chemotherapeutic treatment. Here, we tested the abovementioned CAM-TPP derivatives on chemoresistant triple negative breast cancer (TNBC) cell models, as well as on corresponding CSC-like spheroid cells. We created several relevant models based on TNBC cell lines, particularly MDA-MB-231 and BT-549, to determine their resistance to cyclophosphamide. To create CSC-like cells, parental cells were resuspended in nonadherent conditions to form tumorspheres. We applied TPP derivatives and found that both CAM-C10-TPP and CAM-C14-TPP, but not CAMC4-TPP, significantly reduced the proliferation of TNBC cell lines (Figure 5). We also noticed that higher concentrations of derivatives preferentially inhibited the proliferation of chemoresistant rather than parental cancer cells.

Several TPP-containing compounds have been proposed for the elimination of CSCs by the Lisanti group [39]. In the current work, we studied the effect of CAM-TPP derivatives on CSC-like TNBC cell models. We found a significant decrease in spheroid formation when exposed to CAM-C10-TPP (also to CAM-C14-TPP) (Figure 6A,E). The same compounds reduced the survival of CSCs formed from parental and resistant TNBC cell lines (Figure 6B-D,F-H).

We also compared the effects of the obtained compounds on the suppression of normal cell growth. The preliminary results with CAM-C10-TPP showed that normal human fibroblasts were less affected by submicromolar concentrations of CAM-TPP derivatives than cancer cells (Figure S3). This suggests a pharmacological window to discriminate between healthy and cancer cells.
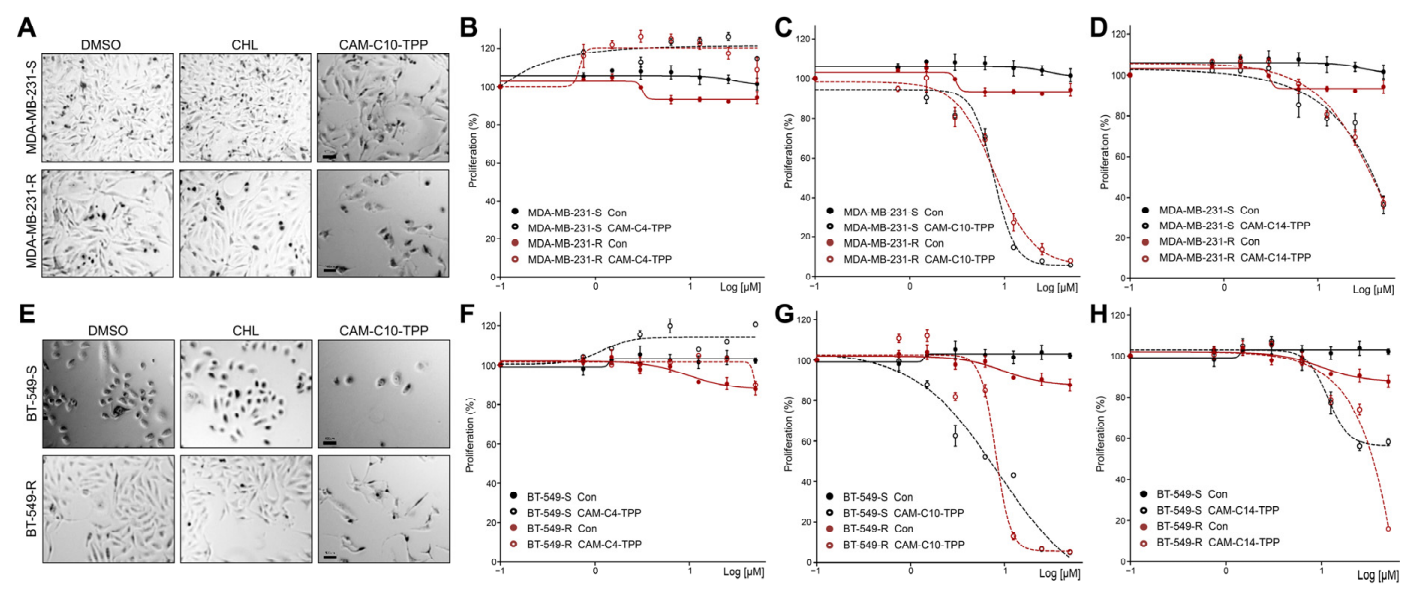

Figure 5. Effect of CAM-TPP derivatives on the cell viability of TNBC cells. MDA-MB-231 (A-D) and BT-549 (E-H) TNBC-sensitive $(S)$ and chemoresistant $(R)$ cells were grown at a $60 \%$ confluence for 3 days with the indicated concentrations of CAM-TPP derivatives. Representative images (A,E) were obtained at $40 \times$ magnification. The scale bar is $10 \mu \mathrm{m}$. Cells were subjected to viability assays. The results represent the mean of 3 independent experiments. The data indicate the mean \pm SEM. The $p$-values, all relative to controls, were statistically significant $(p<0.05)$.

It should be noted that antiproliferative activity was also detected in TPP and Cn-TPP itself, which seems to be related to the depolarization of the mitochondrial membrane potential [27-30]. In this regard, we consider these data on the use of CAM-Cn-TPP derivatives as one of the possible approaches to anti-cancer therapy, requiring more careful study and titration of concentrations and doses. Overall, our data suggest that specific 
targeting of cancer cell mitochondria with dual-acting compounds may have clinical advantages for drug development against resistant forms of cancer.

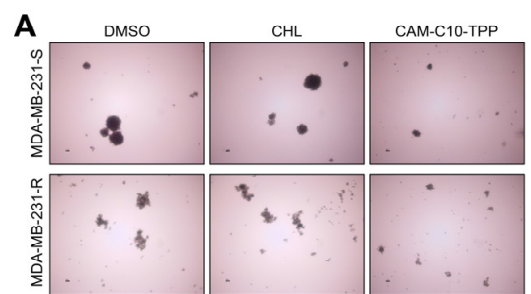

E

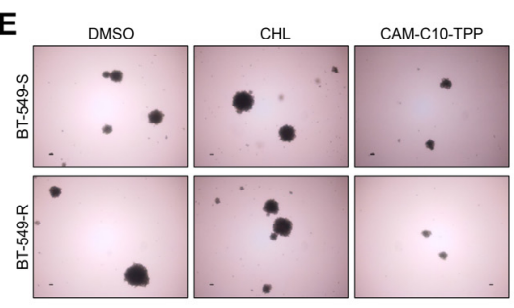

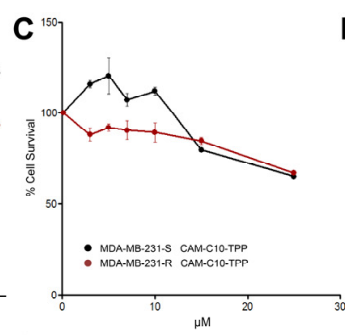

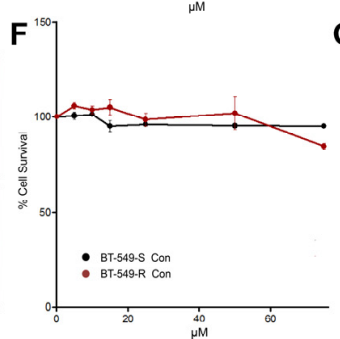

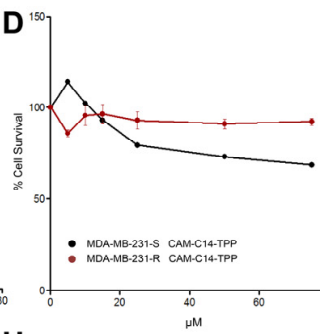
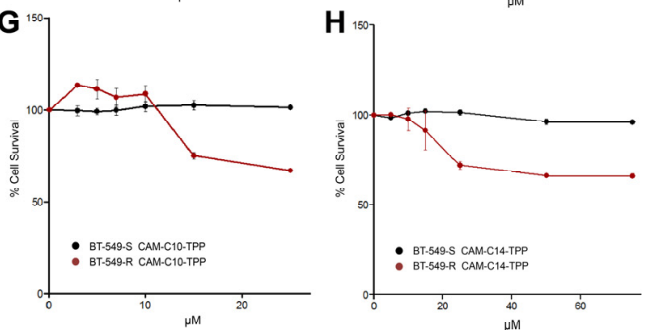

Figure 6. Effect of CAM-TPP derivatives on the cell viability of CSC-like TNBC cells. MDA-MB-231 (A-D) and BT-549 (E-H) TNBC-sensitive (S) and chemoresistant $(\mathrm{R})$ cells were grown under non-adherent conditions for 5 days in the presence of CAM-TPP derivatives to form spheroids. Representative images (A,E) of CAM-C10-TPP-treated cells show a decrease in spheroid size. CSC-like cells were then tested for viability as before. The results are the mean of 3 independent experiments. The data indicate the mean \pm SEM. The $p$-values, all relative to controls, were statistically significant $(p<0.05)$.

\section{Materials and Methods}

\subsection{Chemicals and Materials}

The following reagents were used: chloramphenicol (Sigma, Steinheim, Germany), 1-hydroxysuccinimide (HOSu), N,N'-dicyclohexylcarbodiimide (DCC), 4-aminobutyric acid (GABA), triphenylphosphine, and 11-bromundecanoic acid (Sigma-Aldrich Chemie $\mathrm{GmbH}$, Steinheim, Germany). The fluorescent erythromycin derivative, BODIPY-Ery, was obtained previously [69]. The alkyl-TPPs were obtained according to [17].

\subsection{Synthetic Procedures}

The scheme for the synthesis of chloramphenicol triphenyphosphonium analogs (CAM-C10-TPP and CAM-C14-TPP) is represented in Figure 1. (1R,2R)-2-amino-1-(4nitrophenyl)propane-1,3-diol (chloramphenicol amine, CAM, 2) was obtained via the acid hydrolysis of chloramphenicol (CHL, 1), according to a procedure [55] described in [47,53]. (10-carboxydecyl)(triphenyl)phosphonium bromide (5) was obtained by the condensation of 11-bromoundecanoic acid (3) and triphenylphosphin (4) for $12 \mathrm{~h}$ at $85^{\circ} \mathrm{C}$.

(N-\{[(1R,2R)-1,3-dihydroxy-1-(4-nitrophenyl)propan-2-yl]amino\}-11-oxoundecyl)(triphenyl) phosphonium bromide (CAM-C10-TPP). To a cold solution of $140 \mathrm{mg}(0.25 \mathrm{mmol})$ of (10carboxydecyl)(triphenyl)phosphonium bromide (5) and $30 \mathrm{mg}(0.25 \mathrm{mmol})$ of HOSu in $5 \mathrm{~mL}$ of anhydrous $\mathrm{CH}_{2} \mathrm{Cl}_{2}, 62 \mathrm{mg}(0.3 \mathrm{mmol})$ of DCC was added at $0{ }^{\circ} \mathrm{C}$. The mixture was stirred for $2 \mathrm{~h}$ at $0{ }^{\circ} \mathrm{C}$ and overnight at RT. The formed precipitate was filtered off, and the solvent was removed in vacuo. The residue was dissolved in $1 \mathrm{~mL}$ of DMF, then $62.5 \mathrm{mg}$ $(0.25 \mathrm{mmol})$ of CAM (2), and $52.8 \mu \mathrm{L}(0.375 \mathrm{mmol})$ of DIPEA in $250 \mu \mathrm{L}$ of DMF was added, and the resulted mixture was stirred for $5 \mathrm{~h}$ at $\mathrm{RT}$ and overnight at $4{ }^{\circ} \mathrm{C}$. Then, the reaction mixture was diluted with $15 \mathrm{~mL}$ of water, and $1 \mathrm{~N}$ aqueous $\mathrm{HCl}$ was added dropwise to a neutral $\mathrm{pH}$. The mixture was then extracted with $\mathrm{CHCl}_{3}(3 \times 15 \mathrm{~mL})$, and the combined organic extracts were washed with water $(3 \times 10 \mathrm{~mL})$. The organic layer was dried over anhydrous $\mathrm{Na}_{2} \mathrm{SO}_{4}$, and the volatiles were evaporated in vacuo. The target product was isolated from residue by purification on a silica gel column eluting with a solvent system of $\mathrm{CHCl}_{3}: \mathrm{MeOH}$, 6:1. Yield: $123 \mathrm{mg}(73 \%)$; TLC: $R_{\mathrm{f}}\left(\mathrm{CHCl}_{3}: \mathrm{MeOH}, 6: 1\right)$ 0.3, $R_{\mathrm{f}}\left(\mathrm{CH}_{3} \mathrm{Cl}: \mathrm{MeOH}\right.$, 
9:1) 0.26; LC-MS $m / z$ calculated for $\mathrm{C}_{38} \mathrm{H}_{46} \mathrm{~N}_{2} \mathrm{O}_{5} \mathrm{P}(\mathrm{M})^{+}: 641.3$, found $641.4 ; t_{\mathrm{R}}=1.08 \mathrm{~min}$; and ESI-MS $m / z$ calculated for $\mathrm{C}_{38} \mathrm{H}_{46} \mathrm{~N}_{2} \mathrm{O}_{5} \mathrm{P}(\mathrm{M})^{+}:$: 641.3133, found 641.3149.

$N-[(1 R, 2 R)-1,3-$ dihydroxy-1-(4-nitrophenyl)propan-2-yl]-4-(triphenyl)phosphoniumundecan amidobutamide bromide (CAM-C14-TPP) was obtained as CAM-C10-TPP from $263 \mathrm{mg}$ (0.5 mmol) of (10-carboxydecyl)(triphenyl)phosphonium bromide (5), $58 \mathrm{mg}(0.5 \mathrm{mmol})$ of HOSu, $103 \mathrm{mg}(0.5 \mathrm{mmol})$ of DCC, $200 \mathrm{mg}(0.5 \mathrm{mmol})$ of GABA-CAM.TFA (6), and $253 \mu \mathrm{L}(1.42 \mathrm{mmol})$ of DIPEA. The target product was isolated on a silica gel column eluting with a solvent system of $\mathrm{CHCl}_{3}: \mathrm{MeOH}: \mathrm{NH}_{4} \mathrm{OH}=65: 25: 4$. Yield: $261 \mathrm{mg}(65 \%)$; TLC: $R_{\mathrm{f}}$ $\left(\mathrm{CHCl}_{3}: \mathrm{MeOH}, 5: 1\right)$ 0.53; $R_{\mathrm{f}}\left(\mathrm{CHCl}_{3}: \mathrm{MeOH}: \mathrm{NH}_{4} \mathrm{OH}, 65: 25: 4\right)$ 0.7; LC-MS $m / z$ calculated for $\mathrm{C}_{42} \mathrm{H}_{53} \mathrm{~N}_{3} \mathrm{O}_{6} \mathrm{P}(\mathrm{M})^{+}:$726.4, found 726.7; $t_{\mathrm{R}}=0.50 \mathrm{~min}$; and ESI-MS $\mathrm{m} / \mathrm{z}$ calculated for $\mathrm{C}_{42} \mathrm{H}_{53} \mathrm{~N}_{3} \mathrm{O}_{6} \mathrm{P}(\mathrm{M})^{+}:$726.3667, found 726.3692 .

See also the Supplementary Materials for more detailed procedures, characteristics, and NMR-data.

\subsection{In Vitro Binding Assay}

The binding affinity of CAM-Cn-TPP to E. coli ribosomes was analyzed by a competitionbinding assay using the fluorescently-labeled BODIPY-ERY, as described before [47,52,53,69]. BODIPY-Ery $(16 \mathrm{nM})$ was incubated with the ribosomes $(50 \mathrm{nM})$ in the buffer containing $20 \mathrm{mM}$ HEPES- $\mathrm{KOH}$ (pH 7.5), $50 \mathrm{mM} \mathrm{NH} \mathrm{Cl}_{4}, 10 \mathrm{mM} \mathrm{Mg}\left(\mathrm{CH}_{3} \mathrm{COO}\right)_{2}, 4 \mathrm{mM}$ mercaptoethanol, and $0.05 \%$ Tween- 20 for $30 \mathrm{~min}$ at $25{ }^{\circ} \mathrm{C}$. Solutions of CHL, CAM-Cn-TPP, and CnTPP in different concentration ranges were added to the formed complex. The mixture was incubated for $2 \mathrm{~h}$, until an equilibrium was reached, and the values of fluorescence anisotropy were measured by VICTOR X5 Multilabel Plate Reader (Perkin Elmer, Waltham, MA, USA). The dissociation constants were calculated based on the assumption of the equilibrium competitive binding of two ligands at a single binding site, as described in [70].

\subsection{Detection of the Translation Inhibitors with a pDualrep2 Reporter}

Reporter strain JW55035 [71] $\Delta$ tolC (BW25113) pDualrep2 was used, as previously described [72]. The tested antibiotics, CAM-C10-TPP (10 mM, $1.5 \mu \mathrm{L})$, CAM-C14-TPP (10 $\mathrm{mM}, 1.5 \mu \mathrm{L})$, C10-TPP $(10 \mathrm{mM}, 1.5 \mu \mathrm{L})$, C14-TPP $(10 \mathrm{mM}, 1.5 \mu \mathrm{L})$, CAM $(10 \mathrm{mM}, 1.5 \mu \mathrm{L})$, CAM-Ac (10 mM, $1.5 \mu \mathrm{L})$, chloramphenicol (CHL, $2 \mathrm{mM}, 1 \mu \mathrm{L})$, erythromycin (Ery, $7 \mathrm{mM}$, $1 \mu \mathrm{L}$ ), and levofloxacin (Lev, $70 \mathrm{nM}, 1 \mu \mathrm{L}$ ), were applied to an agar plate that already contained a lawn of the reporter strain. After being incubated overnight at $37^{\circ} \mathrm{C}$, the plate was scanned by ChemiDoc (Bio-Rad) in the modes, "Cy3-blot" for RFP and "Cy5-blot" for Katushka2S.

\subsection{In Vitro Translation Inhibition Assay and Toeprinting Assays}

The inhibition of firefly luciferase synthesis in cell-free translation systems by CAMCn-TPP was tested with an E. coli S30 Extract System for Linear Templates (Promega, Madison, MI, USA). The reactions were programmed with $100 \mathrm{ng}$ of mRNA and were carried out in $5 \mu \mathrm{L}$ aliquots at $37^{\circ} \mathrm{C}$ for $30 \mathrm{~min}$. The activity of in vitro synthesized luciferase was assessed using $5 \mu \mathrm{L}$ of the substrate from the Steady-Glo Luciferase Assay System (Promega).

The inhibition of eukaryotic translation was measured in Rabbit Reticulocyte Lysate (Promega) according to the manufacturer's protocol. The reactions were programmed with $100 \mathrm{ng}$ of Fluc mRNA and were carried out in $5 \mu \mathrm{L}$ aliquots at $37^{\circ} \mathrm{C}$ for $30 \mathrm{~min}$. The activity of the in vitro synthesized luciferase was assessed using $5 \mu \mathrm{L}$ of the substrate from the Steady-Glo Luciferase Assay System (Promega).

The toeprinting assay was carried out using $\operatorname{trpL}$ mRNA as a template, as described in [73], and the reactions were preincubated for $5 \mathrm{~min}$ with $30 \mu \mathrm{M}$ of the tested compound. 


\subsection{Bacteria Inhibition Assays}

3.6.1. Bacterial Strains

To prepare the bacterial suspension, bacterial stock cultures were sub-cultured onto plates with the proper agar medium and incubated overnight at $30^{\circ} \mathrm{C}$ or $37^{\circ} \mathrm{C}$, until reaching the optical density of 1.5 (at $600 \mathrm{~nm}$ ), which was measured on a Varioskan LUX microplate reader (Thermo Scientific, Waltham, MA, USA) or an Ultrospec 1100 pro spectrophotometer (Amersham Biosciences Corp., Piscataway, NJ, USA).

Standard laboratory strains of Bacillus subtilis subs. subtilis Cohn 1872, stains BR151, and 168, Staphylococcus aureus subsp. aureus Rosenbach 1884 strains JCM 2151 and entry MC\#144 (from the Microorganisms Collection of the Moscow State University), Listeria monocytogenes Pirie 1940, Mycobacterium smegmatis Lehmann and Neumann 1899 (MC\#377), and Escherichia coli Castellani and Chalmers 1919, strain JW5503 (with the deletion of tolC gene), which are resistant to the chloramphenicol strains, J53rif, C600rif/pIB55-1, C600rif/pIP162-1, and C600recA naI, were used.

S. aureus was grown in Bacto Tryptic Soy Broth, L. monocytogenes in Brain Heart Infusion Broth, and E. coli in LB. Bacterial cells were grown at $30{ }^{\circ} \mathrm{C}$ or $37^{\circ} \mathrm{C}$ in the appropriate medium at a $140 \mathrm{rpm}$ shaking frequency.

A standard laboratory strain of E. coli JW5503, with the deletion of the tolC gene, referred to here as the $\triangle$ tolC strain, was used to obtain the $\triangle t o l C p C A 24 N-L a c Z$ strain by means of transformation with the plasmid pCA24N-LacZ-harboring chloramphenicol acetyltransferase (cat) gene.

A standard laboratory strain of $B$. subtilis 168 was used to obtain the CHL-resistant strains, B. subtilis $p H T 01-C A T$ and B. subtilis $p H T 01-c f r$, by means of transformation with the corresponding plasmids. Competent cell preparation and transformation procedures were conducted, as reported in [74,75]. The desired colonies were selected at $10 \mu \mathrm{g} / \mathrm{mL}$ of CHL for B. subtilis $p H T 01$ and $5 \mu \mathrm{g} / \mathrm{mL}$ or $3.2 \mu \mathrm{g} / \mathrm{mL}$ of CHL for B. subtilis $p H T 01-c f r$.

\subsubsection{Plasmids}

The pcan24N-lacZ was purified from the JW0335 strain (ASKA-collection), pHT01 (was kindly provided by Dr. Svetlana Dubiley), and the pHT01-cfr plasmid was obtained by the following procedure. The whole pHT01 plasmid sequence was amplified with the primers, $5^{\prime}$-TTGATATGCCTCCTAAATTTTTATC- ${ }^{\prime}$ and $5^{\prime}$-TATGAGATAATGCCGACTG$3^{\prime}$. The $c f r$ gene was amplified with the primers, $5^{\prime}$-acagtcggcattatctcataCTATTGGCTATTTT GATAATTACC $-3^{\prime}$ and $5^{\prime}$-aaatttaggaggcatatcaaATGAATTTTAATAATAAAACAAAGTATG G-3', using the Staphylococcus sp. (cfr+) genome DNA as a template. The joining of the two DNA fragments was performed with the NEBuilder HiFi DNA Assembly Master Mix (NEB), and subsequently, the right clones were selected.

\subsubsection{CAM-Cn-TPP-Dependent Bacterial Growth Suppression Screening of} TolC-Requiring Transporters

The E. coli deletion mutants' panel $[18,60]$ was selected. The selected bacterial strains belonging to the panel were diluted in fresh LB media after overnight growing, and $200 \mu \mathrm{L}$ of bacterial cell cultures $\left(5 \times 10^{5}\right.$ cells $\left./ \mathrm{mL}\right)$ were inoculated into 96 -well plates. The preselected CAM-C14-TPP and CAM-C10-TPP concentrations $(5 \mu \mathrm{M}, 10 \mu \mathrm{M}$, and $20 \mu \mathrm{M})$ were added to each mutant, and the optical density at $620 \mathrm{~nm}$ was measured using a Thermo Scientific Multiskan FC plate reader. The cells were left to grow for $21 \mathrm{~h}$ at $37^{\circ} \mathrm{C}$, and the optical density at $620 \mathrm{~nm}$ was measured. All experiments were performed at least in triplicates.

\subsubsection{MIC Determination}

The MICs for CAM-Cn-TPP and Cn-TPP were determined by Mueller-Hinton broth microdilution, as recommended by CLSI in the Methods for Dilution Antimicrobial Susceptibility Tests for Bacteria that Grow Aerobically, Approved Standard, 9th ed., CLSI document M07-A9, using in-house-prepared panels. The compounds were diluted in a 
96-well microtiter plate to final concentrations ranging from 0.5 to $360 \mu \mathrm{M}$ in a $250-\mu \mathrm{L}$ aliquot of the bacterial suspension, followed by incubation at $37^{\circ} \mathrm{C}$ or $30{ }^{\circ} \mathrm{C}$ for $18 \mathrm{~h}$. The MIC was determined as the lowest concentration that completely inhibited bacterial growth. The bacterial growth was observed visually alongside OD measurements. The experiments were carried out in triplicate.

\subsection{Measurement of the B. subtilis Membrane Potential}

The membrane potential of $B$. subtilis was estimated by measuring the fluorescence of the potential-dependent probe, DiS-C3-(5) [76]. B. subtilis from the overnight culture were seeded into a fresh LB medium, followed by growth for $24 \mathrm{~h}$, until reaching the optical density of 0.8 at $600 \mathrm{~nm}$. Then, the bacteria were diluted 20-fold in a buffer containing $100 \mathrm{mM}$ of $\mathrm{KCl}$ and $10 \mathrm{mM}$ of Tris, $\mathrm{pH}$ 7.4. The fluorescence was measured at $670 \mathrm{~nm}$ (excitation at $630 \mathrm{~nm}$ ) using a Fluorat-02-Panorama fluorimeter.

\subsection{In Vitro Survival Assay (MTT Assay)}

The cytotoxicity of the tested substances was tested using the MTT (3-(4,5-dimethylthiazol2-yl)-2,5-diphenyltetrazolium bromide) assay [62], with some modifications, and 2500 cells per well for the MCF7, HEK293T, and A549 cell lines or 4000 cells per well for the VA-13 cell line were plated in $135 \mu \mathrm{L}$ of DMEM-F12 media (Gibco, Waltham, MA, USA) in a 96-well plate and incubated in the $5 \% \mathrm{CO}_{2}$ incubator for first $16 \mathrm{~h}$, without treatment. Then, $15 \mu \mathrm{L}$ of media-DMSO solutions of the tested substances was added to the cells (the final DMSO concentrations in the media were $1 \%$ or less) and treated cells for $72 \mathrm{~h}$ with $25 \mathrm{nM}-50$ $\mu \mathrm{M}$ (eight dilutions) of our substances (triplicate each), and serial DMSO dilutions and doxorubicin were used as controls. The MTT reagent (Paneco LLC, Moscow, Russia) was then added to cells to a final concentration of $0.5 \mathrm{~g} / \mathrm{L}(10 \times$ stock solution in PBS was used) and incubated for $2.5 \mathrm{~h}$ at $37{ }^{\circ} \mathrm{C}$ in the incubator under an atmosphere of $5 \% \mathrm{CO}_{2}$. The MTT solution was then discarded, and $140 \mu \mathrm{L}$ of DMSO (PharmaMed LLC, Krasnodarsky Krai, Russia) was added. The plates were swayed on a shaker (60 rpm) to dissolve the formazan. The absorbance was measured using a microplate reader (VICTOR X5 Light Plate Reader, PerkinElmer, Waltham, MA, USA) at a wavelength of $565 \mathrm{~nm}$ (in order to measure formazan concentration). The results were used to construct a dose-response graph and to estimate the $\mathrm{CC}_{50}$ value.

\subsection{Cancer Cell Proliferation Assays}

\subsubsection{Cell Lines and Tumoursphere Formation}

The MDA-MB-231 (RRID: CVCL_0062) and BT-549 (RRID: CVCL_1092) cell lines were purchased from ATCC and cultured in DMEM/F12 (Gibco, Life Technologies, 31330-038) supplemented with 10\% FBS, 1\% Pen-Strep, 1\% Sodium Pyruvate, and 1\% L-glutamine. Chemoresistant cell lines were established with continuous treatment for 6 months with the anticancer therapeutic agent, cyclophosphamide (Rcyclo), as previously described [67]. These cell lines were authenticated using short tandem repeat (STR) profiling within the last three years. To obtain CSC-like cells, a single cell suspension was prepared using enzymatic disaggregation ( $1 \times$ Trypsin-EDTA, Gibco, 25300062), and the cells were plated at a density of 10.000-12.000 cells per $\mathrm{ml}$ in a Cancer Stem Cell medium (C-28070, PromoCell, Heidelberg, Germany) in poly-2-hydroxyethyl methacrylate (Poly-HEMA, Santa Cruz Biotechnology, Dallas, TX, USA, sc-253284)-coated plates. Cells of the first generation (G1) were collected 10 days after seeding. The cells were transfected with corresponding compounds or DMSO (control), followed by the abovementioned procedure of tumoursphere formation. The relative numbers of tumourspheres per well were counted manually. The experiments were performed independently at least 2 times, with several replicates.

\subsubsection{Cancer Cell Proliferation}

The survival assay was performed essentially as described earlier [77]. In short, cells were seeded into a 96-well plate, followed by treatment with increasing concentrations 
of the corresponding CAM-TPP derivatives for 3 days. 3-(4,5-dimethylthiazol-2-yl)-2,5diphenyltetrazolium bromide $(0.5 \mathrm{mg} / \mathrm{mL}$ MTT; Sigma-Aldrich) dissolved in media was added to each well. Following incubation for $2 \mathrm{~h}$, the supernatant was carefully removed from the wells, and $100 \mu \mathrm{L}$ of a DMSO:ethanol mix (1:1) was added to each well, followed by shaking for $10 \mathrm{~min}$. The absorbance was measured at $570 \mathrm{~nm}$ in Bio Spec 1601, Shimadzu spectrometer. The OD570 of the DMSO solution in each well was considered to be proportional to the number of cells. The OD570 of the control (treatment without supplement) was considered to be $100 \%$. The results were expressed as the means \pm SEM. The data were analyzed using the GraphPad Prism 7 PRIZM computer software under the license of the Statistical Department (Vall' d Hebron Hospital, Barcelona, Spain).

\subsection{Molecular Dynamics Simulations}

The structure of the E. coli AP-ribosome modeled in [78] was used. A cubic fragment was extracted from this structure in the same manner as in the cited work. CAM-Cn-TPPs, shown in Figure S2 (atom numbering is based on [79]), were docked into this ribosome fragment using the rDock [80] package, with 1000 runs of the optimization process. Then, the pose of the sequent CAM-Cn-TPP, which shows the highest predicted affinity to the ribosome among the other poses of the same compound, was placed in the above-described fragment of ribosome. The constructed system was centered in a tetragonal cell, with dimension of $9.1 \times 9.1 \times 10 \mathrm{~nm}$, so, when it was filled with water, the edges of the ribosome fragment were covered by a solvent layer that was at least $0.9 \mathrm{~nm}$ thick. During the molecular dynamics simulations, residues with at least one atom located within $0.1 \mathrm{~nm}$ from the edge of the simulated ribosome fragment were positionally restrained. Such an approach preserves the local conformational movability of rRNA residues, which is adequate for fitting their conformations to the binding ligand.

The equilibrium molecular dynamics simulation of a $200 \mathrm{~ns}$ length was performed for every constructed system, and the coordinates of the simulated system were recorded every $25 \mathrm{ps}$, with an integration time step of $2 \mathrm{fs}$. The lengths of the covalent bonds with hydrogen atoms were limited by the LINCS algorithm [81]. The velocity rescaling thermostat, with an additional stochastic term [82] at a constant temperature of $300 \mathrm{~K}$ and 0.1 ps coupling time, was applied during the simulation, and the Berendsen barostat [83], with a 5 ps coupling time, was used to support the isotropic constant pressure with periodic boundary conditions. The particle mesh Ewald algorithm, with a $0.125 \mathrm{~nm}$ grid step and the fourth order interpolation, was used to treat long-range electrostatic interactions [84]. TIP4PEW water was used as a solvent. Potassium ions with optimized parameters [85] were added to neutralize the residual negative charge of the system, and they were placed near negatively charged groups [86]. To prevent the elution of magnesium and potassium counterions into the aqueous phase, part of the water molecules were randomly replaced with magnesium, potassium, and chlorine ions, setting the concentrations of $\mathrm{MgCl}_{2}$ to $7 \mathrm{mM}$ and $\mathrm{KCl}$ to $100 \mathrm{mM}$.

Canonical and modified amino acid and nucleotide residues were modeled with parm99sb [87], while CAM-Cn-TPPs were modeled with the GAFF force field [88]. Optimized three-dimensional structures and molecular electrostatic potentials of the newly parameterized residues and compounds were prepared by quantum chemical Hartree-Fock calculations using the $6-31 G^{*}$ basis set. Partial charges were evaluated with the RESP model [89].

GROMACS [90,91] software version 5.1.4 was used to simulate the molecular dynamics simulations and analyze the obtained trajectories, including an analysis of the hydrogen bonds and stacking interactions, which were performed in the same way as in [92], clustering of frames using the GROMOS [93] method, and calculation of the energy of noncovalent interactions: $E_{\text {noncov }}=E_{V d W}+E_{\text {Coulomb }}$. 


\section{Conclusions}

Based on our recent findings from the study of CAM-C4-TPP [51], in this work, we set out to create dual-acting antimicrobial compounds, the structure of which would include an amphenicol fragment of CHL and a TPP cation, connected by linkers of different lengths (CAM-Cn-TPP). We synthesized CAM-C10-TPP and CAM-C14-TPP and examined their ribosomal binding and translational inhibitory properties, as well as their effects on the bacterial membrane. CAM-C10-TPP and CAM-C14-TPP bind to the bacterial ribosome, and their affinity depends on the length of the linker connecting the two chromophores. New CHL analogs inhibit protein synthesis in vitro, such as CAM-C4-TPP, allowing for the formation of multiple peptide bonds, but the mode of action of CAM-Cn-TPP in the bacterial ribosome differs from the site-specific action of $\mathrm{CHL}$, as previously observed for CAM-C4-TPP. Moreover, we showed that CAM-C10-TPP more strongly inhibited the growth of the Gram-positive bacteria, Staphylococcus aureus, Listeria monocytogenes, Bacillus subtilis, and Micobacterium smegmatis, than CHL, and both CAM-C10-TPP and CAM-C14TPP inhibited some CHL-resistant bacterial strains. At the same time, we found that CAM-C10-TPP and CAM-C14-TPP caused a significant decrease in the membrane potential in Bacillus subtilis cells, and, apparently, this effect makes the main contribution to the antibacterial action of the new compounds. Thus, we have shown that based on a ribosome antibiotic (CHL) and a penetrating cation (TPP), it is possible to obtain antimicrobial agents that act simultaneously on the bacterial ribosome and on the bacterial membrane. Such an approach can be developed in the future to create new antibacterial agents by reducing the toxicity of the compounds, for example, using other more physiologically penetrating cations and possibly new antiproliferative agents as well.

Supplementary Materials: The following are available online at https://www.mdpi.com/article/ 10.3390/antibiotics10050489/s1: Detailed procedures of the synthesis and NMR-data; Table S1: Occurrences of hydrogen bonds and stacking interactions of CAM-Cn-TPP, obtained by MD simulations; Table S2: Suppression of the growth of CHL-resistant E. coli strains harboring the CHL acetyltransferase (cat) gene by CAM-C10-TPP (MIC, $\mu \mathrm{M}$ ); Figure S1: Original version of Figure 2D; Figure S2: Triphenylphosphonium derivatives of chloramphenicol amine: CAM-C10-TPP (A) and CAM-C14-TPP (B); Figure S3: Effect of the CAM-C10-TPP derivative on the cell viability of normal (NF) and TNBC cells.

Author Contributions: Synthesis, N.V.S., J.A.P.; purification, N.V.S., J.A.P.; binding assay, A.G.T., J.A.P.; translation inhibition assay, I.A.O., J.A.P.; toeprinting analysis, D.A.L., I.A.O., J.A.P.; membrane potential assays, J.A.P., P.A.N.; 70 ribosomes preparation, A.L.K., A.P.; MTT-tests, D.A.S.; bacteria inhibition assays, Z.Z.K., J.A.P., P.A.N., I.A.V., I.A.O., S.Y.M., S.K.; cancer cell proliferation assays, A.L., E.A.; molecular dynamics modelling, G.I.M.; supervision, S.K., N.V.S., I.A.O., A.A.B.; writingoriginal draft preparation, N.V.S., A.G.T., I.A.O., G.I.M., P.A.N., A.L.; writing-review and editing, N.V.S., I.A.O., P.A.N., D.A.S., A.L., Y.N.A., A.A.B. All authors have read and agreed to the published version of the manuscript.

Funding: This research was funded by RFBR [grants 20-04-00873 to N.V.S. (synthesis of analogs, binding assays, in vitro translation), 20-015-00537 to P.A.N. (potential measurement, screening of TolCcontaining transporters), and 20-54-76002 to I.A.O. (toeprinting and in vitro translation)], President grant MD 2626.2021.1.4 to I.A.O. (bacteria inhibition assays), grants from the Instituto de Salud Carlos III: PI17/02087 to A.L. (cancer cell proliferation assays) by the Ministry of Science and Higher Education of the Russian Federation [grant FENU-2020-0019 to G.I.M. (molecular dynamics simulations)] and by the Government of the Russian Federation [No. AAAA-A17-117120570004-6 to A.A.B.].

Acknowledgments: We thank Yury Polikanov for the critical reading of the manuscript and valuable feedback. We thank V.N. Tashlitsky for the LCMS analyses, Y.K. Grishin and V.I. Polshakov for the NMR spectra, Medved'ko A.V. and M.A. Sukonnikov for the polarimetric data, I.V. Plyushchenko and I.A. Rodin for the high-resolution MS, A. Zalevsky for the software arranging cations on nucleic acids, and the Research Computing Center at Lomonosov Moscow State University for the opportunity to perform molecular dynamics simulations using the "Lomonosov-II" supercomputer. This study was 
carried out using equipment purchased with funds from the Lomonosov Moscow State University Development Program.

Conflicts of Interest: The authors declare no conflict of interest.

\section{References}

1. Gabibov, A.G.; Dontsova, O.A.; Egorov, A.M. Overcoming antibiotic resistance in microorganisms: Molecular mechanisms. Biochemistry 2020, 85, 1289-1291. [CrossRef]

2. Wilson, D.N. Ribosome-targeting antibiotics and mechanisms of bacterial resistance. Nat. Rev. Microbiol. 2013, 12, 35-48. [CrossRef] [PubMed]

3. Lewis, K. At the Crossroads of Bioenergetics and Antibiotic Discovery. Biochemistry 2020, 85, 1469-1483. [CrossRef] [PubMed]

4. Barbachyn, M.R. Recent advances in the discovery of hybrid antibacterial agents. In Annual Reports in Medicinal Chemistry; Macor, J.E., Ed.; Elsevier Academic Press: San Diego, CA, USA, 2008; pp. 281-290. [CrossRef]

5. Pokrovskaya, V.; Baasov, T. Dual-acting hybrid antibiotics: A promising strategy to combat bacterial resistance. Expert Opin. Drug Discov. 2010, 5, 883-902. [CrossRef]

6. Tevyashova, A.N.; Olsufyeva, E.N.; Preobrazhenskaya, M.N. Design of dual action antibiotics as an approach to search for new promising drugs. Russ. Chem. Rev. 2015, 84, 61-97. [CrossRef]

7. Parkes, A.L.; Yule, I.A. Hybrid antibiotics-Clinical progress and novel designs. Expert Opin. Drug Discov. 2016, 11, 665-680. [CrossRef]

8. Tevyashova, A.N.; Bychkova, E.N.; Korolev, A.M.; Isakova, E.B.; Mirchink, P.E.; Osterman, I.A.; Erdei, R.; Szücs, Z.; Batta, G. Synthesis and evaluation of biological activity for dual-acting antibiotics on the basis of azithromycin and glycopeptides. Bioorg. Med. Chem. Lett. 2019, 29, 276-280. [CrossRef] [PubMed]

9. Bremner, J.B.; Ambrus, J.I.; Samosorn, S. Dual action-based approaches to antibacterial agents. Curr. Med. Chem. 2007, 14, 1459-1477. [CrossRef]

10. Lewis, K. Persister Cells. Annu. Rev. Microbiol. 2010, 64, 357-372. [CrossRef] [PubMed]

11. Datta, P.; Gupta, V. Next-generation strategy for treating drug resistant bacteria: Antibiotic hybrids. Indian J. Med Res. 2019, 149, 97-106. [CrossRef] [PubMed]

12. Efimova, S.S.; Tevyashova, A.N.; Olsufyeva, E.N.; Bykov, E.E.; Ostroumova, O.S. Pore-forming activity of new conjugate antibiotics based on amphotericin B. PLOS ONE 2017, 12, e0188573. [CrossRef]

13. Liberman, E.A.; Topaly, V.P.; Tsofina, L.M.; Jasaitis, A.A.; Skulachev, V.P. Mechanism of Coupling of Oxidative Phosphorylation and the Membrane Potential of Mitochondria. Nature 1969, 222, 1076-1078. [CrossRef]

14. Feniouk, B.A.; Skulachev, V.P. Cellular and Molecular Mechanisms of Action of Mitochondria-Targeted Antioxidants. Curr. Aging Sci. 2017, 10, 41-48. [CrossRef]

15. Murphy, M.P.; Smith, R.A.J. Targeting Antioxidants to Mitochondria by Conjugation to Lipophilic Cations. Annu. Rev. Pharmacol. Toxicol. 2007, 47, 629-656. [CrossRef]

16. Severin, F.F.; Severina, I.I.; Antonenko, Y.N.; Rokitskaya, T.I.; Cherepanov, D.A.; Mokhova, E.N.; Vyssokikh, M.Y.; Pustovidko, A.V.; Markova, O.V.; Yaguzhinsky, L.S.; et al. Penetrating cation/fatty acid anion pair as a mitochondria-targeted protonophore. Proc. Natl. Acad. Sci. USA 2009, 107, 663-668. [CrossRef] [PubMed]

17. Khailova, L.S.; Nazarov, P.A.; Sumbatyan, N.V.; Korshunova, G.A.; Rokitskaya, T.I.; Dedukhova, V.I.; Antonenko, Y.N.; Skulachev, V.P. Uncoupling and toxic action of alkyltriphenylphosphonium cations on mitochondria and the bacterium Bacillus subtilis as a function of alkyl chain length. Biochemistry 2015, 80, 1589-1597. [CrossRef] [PubMed]

18. Nazarov, P.A.; Osterman, I.A.; Tokarchuk, A.V.; Karakozova, M.V.; Korshunova, G.A.; Lyamzaev, K.G.; Skulachev, M.V.; Kotova, E.A.; Skulachev, V.P.; Antonenko, Y.N. Mitochondria-targeted antioxidants as highly effective antibiotics. Sci. Rep. 2017, 7, 1394. [CrossRef] [PubMed]

19. Kolesińska, B.; Motylski, R.; Kamiński, Z.J.; Kwinkowski, M.; Kaca, W. Synthesis of P-triazinylphosphonium salts-hybrid molecules with potential antimicrobial activity. Acta Pol. Pharm. 2011, 68, 387-391. [PubMed]

20. Kumari, S.; Jayakumar, S.; Gupta, G.D.; Bihani, S.C.; Sharma, D.; Kutala, V.K.; Sandur, S.K.; Kumar, V. Antibacterial activity of new structural class of semisynthetic molecule, triphenyl-phosphonium conjugated diarylheptanoid. Free Radical Biol. Med. 2019, 1, 140-145. [CrossRef]

21. Kumari, S.; Jayakumar, S.; Bihani, S.C.; Shetake, N.; Naidu, R.; Kutala, V.K.; Sarma, H.D.; Gupta, G.D.; Sandur, S.K.; Kumar, V. Pharmacological characterization of a structurally new class of antibacterial compound, triphenyl-phosphonium conjugated diarylheptanoid: Antibacterial activity and molecular mechanism. J. Biosci. 2020, 45, 147. [CrossRef]

22. Nazarov, P.A.; Kirsanov, R.S.; Denisov, S.S.; Khailova, L.S.; Karakozova, M.V.; Lyamzaev, K.G.; Korshunova, G.A.; Lukyanov, K.A.; Kotova, E.A.; Antonenko, Y.N. Fluorescein derivatives as antibacterial agents acting via membrane depolarization. Biomolecules 2020, 10, 309. [CrossRef] [PubMed]

23. Iaubasarova, I.R.; Khailova, L.S.; Nazarov, P.A.; Rokitskaya, T.I.; Silachev, D.N.; Danilina, T.I.; Plotnikov, E.Y.; Denisov, S.S.; Kirsanov, R.S.; Korshunova, G.A.; et al. Linking 7-nitrobenzo-2-oxa-1,3-diazole (NBD) to triphenylphosphonium yields mitochondriatargeted protonophore and antibacterial agent. Biochemistry 2020, 85, 1578-1590. [CrossRef]

24. Churilov, M.N.; Denisenko, Y.V.; Batyushin, M.M.; Bren, A.B.; Chistyakov, V.A. Prospects of SkQ1 (10-(6'-plastoquinoyl) decyltriphenylphosphonium) application for prevention of oral cavity diseases. Rasayan J. Chem. 2018, 11, 1594-1603. [CrossRef] 
25. Kang, S.; Sunwoo, K.; Jung, Y.; Hur, J.K.; Park, K.H.; Kim, J.S.; Kim, D. Membrane-targeting triphenylphosphonium functionalized ciprofloxacin for methicillin-resistant Staphylococcus aureus (MRSA). Antibiotics 2020, 9, 758. [CrossRef]

26. Pinto, T.; Banerjee, A.; Nazarov, P.A. Triphenyl phosphonium-based substances are alternatives to common antibiotics. Bull. Russ. State Med. Univ. 2018, 7, 16-25. [CrossRef]

27. Balczewski, P.; Skalik, J.; Nawrot, B.; Cieslak, M.; Kazmierczak-Baranska, J. Triphenylphosphonium Salts for Use in Cancer Therapy. European Patent Office 15,460,043.1, 13 August 2015.

28. Sparey, T.; Ratcliffe, A.; Hallett, D.; Cochrane, E.; Lassalle, G.; Frodbise, A.; Stevenson, B. Triphenylphosphonium-Tethered Tetracycyclines for Use in Treating Cancer; World Intellectual Property Organization: Geneva, Switzerland, 2018.

29. Tsepaeva, O.V.; Nemtarev, A.V.; Salikhova, T.I.; Abdullin, T.I.; Grigor Eva, L.R.; Khozyainova, S.A.; Mironov, V.F. Synthesis, anticancer, and antibacterial activity of betulinic and betulonic acid C-28-triphenylphosphonium conjugates with variable alkyl linker length. Anticancer Agents Med Chem. 2020, 20, 286-300. [CrossRef] [PubMed]

30. Tsepaeva, O.V.; Salikhova, T.I.; Grigor'eva, L.R.; Ponomaryov, D.V.; Dang, T.; Ishkaeva, R.A.; Abdullin, T.I.; Nemtarev, A.V.; Mironov, V.F. Synthesis and in vitro evaluation of triphenylphosphonium derivatives of acetylsalicylic and salicylic acids: Structure-dependent interactions with cancer cells, bacteria, and mitochondria. Med. Chem. Res. 2021, 30, 925-939. [CrossRef]

31. Weinberg, S.E.; Chandel, N.S. Targeting mitochondria metabolism for cancer therapy. Nat. Chem. Biol. 2015, 11, 9-15. [CrossRef]

32. Dairkee, S.H.; Hackett, A.J. Differential retention of rhodamine 123 by breast carcinoma and normal human mammary tissue. Breast Cancer Res. Treat. 1991, 18, 57-61. [CrossRef] [PubMed]

33. Guerra, F.; Arbini, A.A.; Moro, L. Mitochondria and cancer chemoresistance. Biochim. Biophys. Acta. Bioenergy 2017, 1858, 686-699. [CrossRef] [PubMed]

34. Lleonart, M.E.; Abad, E.; Graifer, D.; Lyakhovich, A. Reactive oxygen species-mediated autophagy defines the fate of cancer stem cells. Antioxid. Redox Signal. 2018, 28, 1066-1079. [CrossRef]

35. Jones, C.L.; Inguva, A.; Jordan, C.T. Targeting energy metabolism in cancer stem cells: Progress and challenges in leukemia and solid tumors. Cell Stem Cell 2021, 28, 378-393. [CrossRef]

36. Han, X.; Su, R.; Huang, X.; Wang, Y.; Kuang, X.; Zhou, S.; Liu, H. Triphenylphosphonium-modified mitochondria-targeted paclitaxel nanocrystals for overcoming multidrug resistance. Asian J. Pharm. Sci. 2019, 14, 569-580. [CrossRef]

37. Lu, A.T.; Quach, A.; Wilson, J.G.; Reiner, A.P.; Aviv, A.; Raj, K.; Hou, L.; Baccarelli, A.A.; Li, Y.; Stewart, J.D.; et al. DNA methylation GrimAge strongly predicts lifespan and healthspan. Aging 2019, 11, 303-327. [CrossRef]

38. Liu, H.N.; Guo, N.N.; Wang, T.T.; Guo, W.W.; Lin, M.T.; Huang-Fu, M.Y.; Vakili, M.R.; Xu, W.H.; Chen, J.J.; Wei, Q.C.; et al. Mitochondrial targeted doxorubicin-triphenylphosphonium delivered by hyaluronic acid modified and $\mathrm{pH}$ responsive nanocarriers to breast tumor: In vitro and in vivo studies. Mol. Pharm. 2018, 15, 882-891. [CrossRef] [PubMed]

39. Ozsvari, B.; Sotgia, F.; Lisanti, M.P. Exploiting mitochondrial targeting signal(s), TPP and bis-TPP, for eradicating cancer stem cells (CSCs). Aging 2018, 10, 229-240. [CrossRef] [PubMed]

40. Kalghatgi, S.; Spina, C.S.; Costello, J.C.; Liesa, M.; Morones-Ramirez, J.R.; Slomovic, S.; Molina, A.; Shirihai, O.S.; Collins, J.J. Bactericidal antibiotics induce mitochondrial dysfunction and oxidative damage in Mammalian cells. Sci. Transl. Med. 2013, 5, 192ra85. [CrossRef]

41. Lleonart, M.E.; Grodzicki, R.; Graifer, D.M.; Lyakhovich, A. Mitochondrial dysfunction and potential anticancer therapy. Med. Res. Rev. 2017, 37, 1275-1298. [CrossRef] [PubMed]

42. Fiorillo, M.; Lamb, R.; Tanowitz, H.B.; Cappello, A.R.; Martinez-Outschoorn, U.E.; Sotgia, F.; Lisanti, M.P. Bedaquiline, an FDA-approved antibiotic, inhibits mitochondrial function and potently blocks the proliferative expansion of stem-like cancer cells (CSCs). Aging 2016, 8, 1593-1607. [CrossRef] [PubMed]

43. Kuntz, E.M.; Baquero, P.; Michie, A.M.; Dunn, K.; Tardito, S.; Holyoake, T.L.; Helgason, G.V.; Gottlieb, E. Targeting mitochondrial oxidative phosphorylation eradicates therapy-resistant chronic myeloid leukemia stem cells. Nat. Med. 2017, 23, 1234-1240. [CrossRef] [PubMed]

44. Nissen, P.; Hansen, J.; Ban, N.; Moore, P.B.; Steitz, T.A. The structural basis of ribosome activity in peptide bond synthesis. Science 2000, 289, 920-930. [CrossRef] [PubMed]

45. Contreras, A.; Vazquez, D. Cooperative and antagonistic interactions of peptidyl-tRNA and antibiotics with bacterial ribosomes. Eur. J. Biochem. 1977, 74, 539-547. [CrossRef] [PubMed]

46. Dinos, G.P.; Athanassopoulos, C.M.; Missiri, D.A.; Giannopoulou, P.C.; Vlachogiannis, I.A.; Papadopoulos, G.E.; Papaioannou, D.; Kalpaxis, D.L. Chloramphenicol derivatives as antibacterial and anticancer agents: Historic problems and current solutions. Antibiotics 2016, 5, 20. [CrossRef] [PubMed]

47. Tereshchenkov, A.G.; Dobosz-Bartoszek, M.; Osterman, I.A.; Marks, J.; Sergeeva, V.A.; Kasatsky, P.; Komarova, E.S.; Stavrianidi, A.N.; Rodin, I.A.; Konevega, A.L.; et al. Binding and action of amino acid analogs of chloramphenicol upon the bacterial ribosome. J. Mol. Biol. 2018, 430, 842-852. [CrossRef]

48. Mamos, P.; Krokidis, M.G.; Papadas, A.; Karahalios, P.; Starosta, A.L.; Wilson, D.N.; Kalpaxis, D.L.; Dinos, G.P. On the use of the antibiotic chloramphenicol to target polypeptide chain mimics to the ribosomal exit tunnel. Biochimie 2013, 95, 1765-1772. [CrossRef] [PubMed]

49. Kostopoulou, O.N.; Kouvela, E.C.; Magoulas, G.E.; Garnelis, T.; Panagoulias, I.; Rodi, M.; Papadopoulos, G.; Mouzaki, A.; Dinos, G.P.; Papaioannou, D.; et al. Conjugation with polyamines enhances the antibacterial and anticancer activity of chloramphenicol. Nucleic Acids Res. 2014, 42, 8621-8634. [CrossRef] 
50. Giannopoulou, P.C.; Missiri, D.A.; Kournoutou, G.G.; Sazakli, E.; Papadopoulos, G.E.; Papaioannou, D.; Dinos, G.P.; Athanassopoulos, C.M.; Kalpaxis, D.L. New Chloramphenicol Derivatives from the Viewpoint of Anticancer and Antimicrobial Activity. Antibiotics 2019, 8, 9. [CrossRef] [PubMed]

51. Chen, C.-W.; Pavlova, J.A.; Lukianov, D.A.; Tereshchenkov, A.G.; Makarov, G.I.; Khairullina, Z.Z.; Tashlitsky, V.N.; Paleskava, A.; Konevega, A.L.; Bogdanov, A.A.; et al. Binding and action of triphenylphosphonium analog of chloramphenicol upon the bacterial ribosome. Antibiotics 2021, 10, 390. [CrossRef]

52. Yan, K.; Hunt, E.; Berge, J.; May, E.; Copeland, R.A.; Gontarek, R.R. Fluorescence polarization method to characterize macrolideribosome interactions. Antimicrob. Agents Chemother. 2005, 49, 3367-3372. [CrossRef]

53. Tereshchenkov, A.G.; Shishkina, A.V.; Tashlitsky, V.N.; Korshunova, G.A.; Bogdanov, A.A.; Sumbatyan, N.V. Interaction of chloramphenicol tripeptide analogs with ribosomes. Biochemistry 2016, 81, 392-400. [CrossRef]

54. Osterman, I.A.; Komarova, E.S.; Shiryaev, D.I.; Korniltsev, I.A.; Khven, I.M.; Lukyanov, D.A.; Tashlitsky, V.N.; Serebryakova, M.V.; Efremenkova, O.V.; Ivanenkov, Y.A.; et al. Sorting out antibiotics' mechanisms of action: A double fluorescent protein reporter for high-throughput screening of ribosome and DNA biosynthesis inhibitors. Antimicrob. Agents Chemother. 2016, 60, 7481-7489. [CrossRef]

55. Rebstock, M.C.; Crooks, H.M.; Controulis, J.; Bartz, Q.R. Chloramphenicol (chloromycetin). IV. Chemical studies. J. Am. Chem. Soc. 1949, 71, 2458-2462. [CrossRef]

56. Marks, J.; Kannan, K.; Roncase, E.J.; Klepacki, D.; Kefi, A.; Orelle, C.; Vázquez-Laslop, N.; Mankin, A.S. Context-specific inhibition of translation by ribosomal antibiotics targeting the peptidyl transferase center. Proc. Natl. Acad. Sci. USA 2016, 113, 12150-12155. [CrossRef] [PubMed]

57. Hartz, D.; McPheeters, D.S.; Traut, R.; Gold, L. Extension inhibition analysis of translation initiation complexes. Methods Enzymol. 1988, 164, 419-425. [CrossRef] [PubMed]

58. Makarova, T.M. Investigation of Allosteric Phenomena in the Bacterial Ribosome by Molecular Dynamics Simulations Method. Ph.D. Thesis, Lomonosov Moscow State University, Moscow, Russia, 21 September 2020.

59. Makarov, G.I.; Makarova, T.M. A noncanonical binding site of chloramphenicol revealed via molecular dynamics simulations. Biochim. Biophys. Acta Gen. Subj. 2018, 1862, 2940-2947. [CrossRef]

60. Nazarov, P.A.; Kotova, E.A.; Skulachev, V.P.; Antonenko, Y.N. Genetic variability of the AcrAB-TolC multidrug efflux pump underlies SkQ1 resistance in gram-negative bacteria. Acta Nat. 2019, 11, 93-98. [CrossRef] [PubMed]

61. Long, K.S.; Poehlsgaard, J.; Kehrenberg, C.; Schwarz, S.; Vester, B. The Cfr rRNA methyl-transferase confers resistance to phenicols, lincosamides, oxazolidinones, pleuromutilins, and streptogramin A antibiotics. Antimicrob. Agents Chemother. 2006, 50, 2500-2505. [CrossRef]

62. Mosmann, T. Rapid colorimetric assay for cellular growth and survival: Application to proliferation and cytotoxicity assays. J. Immunol. Methods 1983, 65, 55-63. [CrossRef]

63. Antonenko, Y.N.; Avetisyan, A.V.; Bakeeva, L.E.; Chernyak, B.V.; Chertkov, V.A.; Domnina, L.V.; Ivanova, O.Y.; Izyumov, D.S.; Khailova, L.S.; Klishin, S.S.; et al. Mitochondria-targeted plastoquinone derivatives as tools to interrupt execution of the aging program. 1. Cationic plastoquinone derivatives: Synthesis and in vitro studies. Biochemistry 2008, 73, 1273-1287. [CrossRef]

64. Ross, M.F.; Prime, T.A.; Abakumova, I.; James, A.M.; Porteous, C.M.; Smith, R.A.; Murphy, M.P. Rapid and extensive uptake and activation of hydrophobic triphenylphosphonium cations within cells. Biochem. J. 2008, 411, 633-645. [CrossRef]

65. Neuzil, J.; Dong, L.F.; Rohlena, J.; Truksa, J.; Ralph, S.J. Classification of mitocans, anti-cancer drugs acting on mitochondria. Mitochondrion 2013, 13, 199-208. [CrossRef]

66. Ralph, S.J.; Low, P.; Dong, L.; Lawen, A.; Neuzil, J. Mitocans: Mitochondrial targeted anti-cancer drugs as improved therapies and related patent documents. Recent Pat. Anticancer Drug Discov. 2006, 1, 327-346. [CrossRef]

67. Abad, E.; García-Mayea, Y.; Mir, C.; Sebastian, D.; Zorzano, A.; Potesil, D.; Zdrahal, Z.; Lyakhovich, A.; Lleonart, M.E. Common metabolic pathways implicated in resistance to chemotherapy point to a key mitochondrial role in breast cancer. Mol. Cell Proteom. 2019, 18, 231-244. [CrossRef]

68. Esner, M.; Graifer, D.; Lleonart, M.E.; Lyakhovich, A. Targeting cancer cells through antibiotics-induced mitochondrial dysfunction requires autophagy inhibition. Cancer Lett. 2017, 384, 60-69. [CrossRef] [PubMed]

69. Shishkina, A.V.; Makarov, G.I.; Tereshchenkov, A.G.; Korshunova, G.A.; Sumbatyan, N.V.; Golovin, A.V.; Svetlov, M.S.; Bogdanov, A.A. Conjugates of amino acids and peptides with 5-O-mycaminosyltylonolide and their interaction with the ribosomal exit tunnel. Bioconjug. Chem. 2013, 24, 1861-1869. [CrossRef]

70. Wang, Z.X. An exact mathematical expression for describing competitive binding of two different ligands to a protein molecule. FEBS Lett. 1995, 360, 111-114. [CrossRef]

71. Baba, T.; Ara, T.; Hasegawa, M.; Takai, Y.; Okumura, Y.; Baba, M.; Datsenko, K.A.; Tomita, M.; Wanner, B.L.; Mori, H. Construction of Escherichia coli K-12 in-frame, single-gene knockout mutants: The Keio collection. Mol. Syst. Biol. 2006, 2. [CrossRef]

72. Zakalyukina, Y.V.; Birykov, M.V.; Lukianov, D.A.; Shiriaev, D.I.; Komarova, E.S.; Skvortsov, D.A.; Kostyukevich, Y.; Tashlitsky, V.N.; Polshakov, V.I.; Nikolaev, E.; et al. Nybomycin-producing Streptomyces isolated from carpenter ant Camponotus vagus. Biochimie 2019, 160, 93-99. [CrossRef] [PubMed]

73. Orelle, C.; Szal, T.; Klepacki, D.; Shaw, K.J.; Vázquez-Laslop, N.; Mankin, A.S. Identifying the targets of aminoacyl-tRNA synthetase inhibitors by primer extension inhibition. Nucleic. Acids Res. 2013, 41, e144. [CrossRef] [PubMed] 
74. Cao, G.; Zhang, X.; Zhong, L.; Lu, Z. A modified electro-transformation method for Bacillus subtilis and its application in the production of antimicrobial lipopeptides. Biotechnol. Lett. 2011, 33, 1047-1051. [CrossRef]

75. Lu, Y.P.; Zhang, C.; Lv, F.X.; Bie, X.M.; Lu, Z.X. Study on the electro-transformation conditions of improving transformation efficiency for Bacillus subtilis. Lett. Appl. Microbiol. 2012, 55, 9-14. [CrossRef] [PubMed]

76. Antonenko, Y.N.; Denisov, S.S.; Khailova, L.S.; Nazarov, P.A.; Rokitskaya, T.; Tashlitsky, V.N.; Firsov, A.M.; Korshunova, G.A.; Kotova, E.A. Alkyl-substituted phenylamino derivatives of 7-nitrobenz-2-oxa-1,3-diazole as uncouplers of oxidative phosphorylation and antibacterial agents: Involvement of membrane proteins in the uncoupling action. Biochim. Biophys. Acta Biomembr. 2017, 1859, 377-387. [CrossRef]

77. Abad, E.; Civit, L.; Potesil, D.; Zdrahal, Z.; Lyakhovich, A. Enhanced DNA damage response through RAD50 in triple negative breast cancer resistant and cancer stem-like cells contributes to chemoresistance. FEBS J. 2020. [CrossRef]

78. Makarov, G.I.; Makarova, T.M. A noncanonical binding site of linezolid revealed via molecular dynamics simulations. J. Comput. Aided Mol. Des. 2019, 34, 281-291. [CrossRef] [PubMed]

79. Schlünzen, F.; Zarivach, R.; Harms, J.; Bashan, A.; Tocilj, A.; Albrecht, R.; Yonath, A.; Franceschi, F. Structural basis for the interaction of antibiotics with the peptidyl transferase centre in eubacteria. Nature 2001, 413, 814-821. [CrossRef] [PubMed]

80. Ruiz-Carmona, S.; Alvarez-Garcia, D.; Foloppe, N.; Garmendia-Doval, A.B.; Juhos, S.; Schmidtke, P.; Barril, X.; Hubbard, R.E.; Morley, S.D. rDock: A fast, versatile and open source program for docking ligands to proteins and nucleic acids. PLoS Comput. Biol. 2014, 10, e1003571. [CrossRef] [PubMed]

81. Hess, B.; Bekker, H.; Berendsen, H.J.C.; Fraaije, J.G.E.M. LINCS: A linear constraint solver for molecular simulations. J. Comput. Chem. 1997, 18, 1463-1472. [CrossRef]

82. Bussi, G.; Donadio, D.; Parrinello, M. Canonical sampling through velocity rescaling. J. Chem. Phys. 2007, 126, 014101-014102. [CrossRef] [PubMed]

83. Berendsen, H.J.C.; Postma, J.P.M.; van Gunsteren, W.F.; DiNola, A.; Haak, J.R. Molecular dynamics with coupling to an external bath. J. Chem. Phys. 1984, 81, 3684-3690. [CrossRef]

84. Darden, T.; York, D.; Pedersen, L. Particle mesh Ewald: AnN $\log (\mathrm{N})$ method for Ewald sums in large systems. J. Chem. Phys. 1993, 98, 10089-10092. [CrossRef]

85. Horn, H.W.; Swope, W.C.; Pitera, J.W.; Madura, J.D.; Dick, T.J.; Hura, G.L.; Head-Gordon, T. Development of an improved four-site water model for biomolecular simulations: TIP4P-Ew. J. Chem. Phys. 2004, 120, 9665-9678. [CrossRef] [PubMed]

86. Athavale, S.S.; Petrov, A.S.; Hsiao, C.; Watkins, D.; Prickett, C.D.; Gossett, J.J.; Lie, L.; Bowman, J.C.; O’Neill, E.; Bernier, C.R.; et al. RNA folding and catalysis mediated by iron (II). PLoS ONE 2012, 7, e38024. [CrossRef] [PubMed]

87. Hornak, V.; Abel, R.; Okur, A.; Strockbine, B.; Roitberg, A.; Simmerling, C. Comparison of multiple Amber force fields and development of improved protein backbone parameters. Proteins 2006, 65, 712-725. [CrossRef]

88. Wang, J.; Wolf, R.M.; Caldwell, J.W.; Kollman, P.A.; Case, D.A. Development and testing of a general amber force field. J. Comput. Chem. 2004, 25, 1157-1174. [CrossRef] [PubMed]

89. Bayly, C.I.; Cieplak, P.; Cornell, W.; Kollman, P.A. A well-behaved electrostatic potential based method using charge restraints for deriving atomic charges: The RESP model. J. Phys. Chem. 1993, 97, 10269-10280. [CrossRef]

90. Van der Spoel, D.; Lindahl, E.; Hess, B.; Groenhof, G.; Mark, A.E.; Berendsen, H.J. GROMACS: Fast, flexible, and free. J. Comput. Chem. 2005, 26, 1701-1718. [CrossRef]

91. Hess, B.; Kutzner, C.; van der Spoel, D.; Lindahl, E. GROMACS 4: Algorithms for highly efficient, load-balanced, and scalable molecular simulation. J. Chem. Theory Comput. 2008, 4, 435-447. [CrossRef]

92. Makarov, G.I.; Sumbatyan, N.V.; Bogdanov, A.A. Structural insight into interaction between C20 phenylalanyl derivative of tylosin and ribosomal tunnel. Biochemistry 2017, 82, 925-932. [CrossRef]

93. Daura, X.; Gademann, K.; Jaun, B.; Seebach, D.; van Gunsteren, W.F.; Mark, A.E. Peptide folding: When simulation meets experiment. Angew. Chem. Int. Ed. 1999, 38, 236-240. [CrossRef] 